\title{
东北地区水獭分布格局与保护优先区识别
}

张超 ${ }^{1}$, 陈敏豪 ${ }^{1}$, 杨立 ${ }^{2}$, 庄鸿飞 ${ }^{1}$, 武曙红 ${ }^{1}$, 湛振杰 ${ }^{1}$, 王嘉栋 ${ }^{1}$, 奕晓峰 ${ }^{*}$

1. 北京林业大学生态与自然保护学院, 北京 $100083 ; 2$. 中山大学生命与科学学院, 广州 510275

摘要: 水獭是水生生态系统重要的指示种和旗舰种, 由于强烈的人为干扰, 中国的水獭种群数量大幅下降, 部分区域已局部 灭绝。然而目前国内对水獭的调查和研究非常有限, 本底不清的状况已经严重影响到水獭的野外保育工作。本文以东北地区 的欧亚水獭指名亚种 (Lutra lutra lutra)为研究对象, 基于2016-2020年的调查数据, 使用组合建模的方法评估了水獭的潜在分 布区; 利用地理信息系统和系统保护规划软件分析了水獭的保护优先区并计算了各省级行政区内水獭潜在分布区和保护优 先区面临的人类压力; 结合国家级自然保护区的空间布局分析了水獭的保护现状, 并以内蒙古森工集团、大兴安岭林业集团、 伊春森工集团三大国有林区为例分析了重点国有林区在水獭保护中的作用。结果表明: (1)水獭潜在分布区和保护优先区面积 分别为 $104,515.04 \mathrm{~km}^{2}$ 和 $45,448.99 \mathrm{~km}^{2}$, 其中大兴安岭的水獭保护优先区集中连片, 并与小兴安岭的保护优先区相连, 栖息地 之间没有明显地理隔离, 是维持东北地区水獭种群稳定的重中之重; (2)水獭面临的人类压力大小依次为: 辽宁 $>$ 吉林 $>$ 黑 龙江 > 内蒙古; (3)研究区内 110 个国家级自然保护区中有 63 个包含水獭潜在分布区, 覆盖面积为 $12,168.93 \mathrm{~km}^{2}$, 仅占水獭潜 在分布区面积的 $11.64 \%$, 其中 32 个国家级自然保护区包含水獭保护优先区, 占水獭保护优先区面积的 $10.88 \%$; (4)三大国有林 区涵盖了 $71.18 \%$ 的水獭潜在分布区和 $79.26 \%$ 的保护优先区(面积分别为 $74,390.89 \mathrm{~km}^{2}$ 和 $36,022.22 \mathrm{~km}^{2}$ )。由此可见，尽管水獭 潜在分布区中国家级自然保护区占比较低, 但是在天然林全面禁伐的背景下, 重点国有林区可能在未来东北地区的生物多样 性保护中发挥更大作用, 因此我们建议将重点国有林区中具有重要保护价值的区域逐步纳入以国家公园为主体的自然保护 地体系中, 以实现生物多样性的系统性和完整性保护。最后, 本文结合研究结果和实地调研提出以下保护建议: (1)加强对河 流污染物的管理; (2)控制渔民捕鱼强度; (3)开展全面的水獭专项调查并建立长期的监测体系; (4)加大对水獭的科研投入; (5) 加强宣传力度, 提升公众保护意识。

关键词: 欧亚水獭; 组合模型; 分布; 保护优先区; 国有林区

张超, 陈敏豪, 杨立, 庄鸿飞, 武曙红, 湛振杰, 王嘉栋, 奕晓峰 (2022) 东北地区水獭分布格局与保护优先区识别. 生物多样性, 30, 21157. doi: 10.17520/biods.2021157.

Zhang C, Chen MH, Yang L, Zhuang HF, Wu SH, Zhan ZJ, Wang JD, Luan XF (2022) Distribution pattern and identification of conservation priority areas of the otter in Northeast China. Biodiversity Science, 30, 21157. doi: 10.17520/biods.2021157.

\section{Distribution pattern and identification of conservation priority areas of the otter in Northeast China}

Chao Zhang ${ }^{1}$, Minhao Chen ${ }^{1}$, Li Yang ${ }^{2}$, Hongfei Zhuang ${ }^{1}$, Shuhong $\mathrm{Wu}^{1}$, Zhenjie Zhan ${ }^{1}$, Jiadong Wang ${ }^{1}$, Xiaofeng Luan $^{1 *}$

1 School of Ecology and Nature Conservation, Beijing Forestry University, Beijing 100083

2 School of Life Sciences, Sun Yat-sen University, Guangzhou 510275

\section{ABSTRACT}

Aims: The otter is an indicator and flagship species of aquatic ecosystems. Its populations have undergone a drastic decline in China, and have become locally extinct in some regions due to anthropogenic disturbance. However, the current literature on otters in China is inadequate, which has subsequently affected conservation of the species. We aim to assess the potential distribution and conservation priority areas of the Eurasian otter (Lutra lutra) in Northeast China.

收稿日期: 2021-04-24; 接受日期: 2021-08-26

基金项目: 国家自然科学基金(31972944; 32000352)

* 通讯作者 Author for correspondence. E-mail: luanxiaofeng@bjfu.edu.cn 
Methods: In this study, we integrated species distribution models with otter survey data from 2016 to 2020 to assess Eurasian otter distribution. Then, we used the geographic information system and core-area zonation algorithm in Zonation 4.00 to identify conservation priority areas for otter protection. Using the anthropogenic pressures layer, we also evaluated anthropogenic stressors in each province. Then, we analyzed the conservation status of the otter based on the spatial distribution of national nature reserves. Furthermore, we used Inner Mongolia Forest Industry Group, Daxing'anling Forestry Group and Yichun Forest Industry Group as case studies to analyze the role of state-owned forest areas for otter conservation.

Results: The results demonstrate that potential distribution and conservation priority areas cover $104,515.04 \mathrm{~km}^{2}$ and $45,448.99 \mathrm{~km}^{2}$, respectively. Large swathes of conservation priority areas remain for the otter in Daxing'anling which are connected with conservation priority areas in Xiaoxing'anling and there is no obvious geographical boundary between them. Therefore, these regions are mandatory to conserve to maintain the stability of otter populations in Northeast China. Otters in the Liaoning Province faced the greatest anthropogenic pressures, followed by the Jilin Province and Heilongjiang Province. Otters in the Inner Mongolia Autonomous Region faced the lowest amount of pressure. There is potential distribution for the otter in 63 nature reserves and conservation priority areas in 32 nature reserves out of the 110 reserves in the region. The study area includes $11.64 \%$ of the otter's potential distribution and $10.88 \%$ of conservation priority areas. Three state-owned forest industry groups cover $71.18 \%$ of the potential distribution of the otter $\left(74,390.89 \mathrm{~km}^{2}\right)$ and $79.26 \%$ of the conservation priority areas $\left(36,022.22 \mathrm{~km}^{2}\right)$.

Conclusions: This study indicates that state-owned forest areas may play a greater role in the protection of biodiversity following a comprehensive ban on logging in natural forests. Therefore, we propose that areas with important conservation value in state-owned forest land should be gradually included under the protections of national parks in order to achieve systematic and complete protection of biodiversity. Finally, we suggest: (1) strengthening the management of river pollutions; (2) reducing fishing intensity; (3) a long-term field monitoring network be established to study population changes in otters; (4) increasing the investment in scientific research on otters; and (5) raising awareness of otter conservation through public education.

Key words: Eurasian otter; ensemble models; distribution; conservation priority areas; state-owned forest areas

水獭属哺乳纲食肉目鼠科，曾经是古北区分布 最广的哺乳动物之一, 因其对水质高度敏感并处于 食物链的顶端, 也是水生生态系统的指示种和旗舰 种 (Mason \& MacDonald, 1986; Kruuk, 2006; Cianfrani et al, 2011; Zhang et al, 2018)。然而受大规 模人为活动的影响, 全球水獭种群和栖息地已遭受 严重破坏(Roos et al, 2015; Gomez et al, 2016)。中国 分布的欧亚水獭(Lutra lutra)、小爪水獭(Aonyx cinereus)和江獭(Lutrogale perspicillata)自20世纪以 来种群经历了断崖式的下降, 部分地区已经野外灭 绝(雷伟和李玉春, 2008; 朴正吉, 2011; Li \& Chan, 2017)。IUCN濒危物种红色名录将欧亚水獭列为近 危(NT), 小爪水獭和江獭列为易危(VU)。在我国, 2021年调整后的《国家重点保护野生动物名录》将 3 种水獭列为国家二级重点保护野生动物。

建立自然保护地和实施天然林保护工程是我 国保护生物多样性的重要途径(刘惠兰和黄俊毅, 2015; 唐小平等, 2019)。多年来, 随着自然保护地体 系的构建和天然林的全面商业性禁伐, 部分区域珍 稀物种的种群规模已经开始恢复(黄宝荣等, 2018)。
但日趋濒危的水獭并没有得到应有的关注，国内对 水獭的调查和研究相当有限 (Li \& Chan, 2018; Zhang et al, 2018)。此外, 由于水獭作为水生野生动 物由渔业部门管理, 其栖息地在空间上又主要归林 草部门管理, 这样的管理方式也对水獭的调查、研 究和保护造成了诸多不便(Zhang et al, 2018)。本底 不清、家底不明的状况已严重影响水獭的野外保育 工作。

掌握物种的地理分布情况并对其保护优先区 进行识别是保护生物学的重要基础, 同时也能为保 护决策的制定和保护地规划等提供基础数据 (Guisan et al, 2013; Yang et al, 2021)。有学者曾利用 多种数据来源分析了中国水獭 400 年的分布变化, 结果显示东北地区和西南地区是目前水獭的主要 分布区(Zhang et al, 2018)。但大尺度研究往往存在 基础数据精度较低等问题, 因而不能较好地指导中 小尺度的保护规划(Hu et al, 2019)。东北林区是我国 最大的国有林区，是建立以国家公园为主体的自然 保护地体系的重点地区, 也是中国北方水獭分布最 为集中的区域(郝占庆等，1998; Zhang et al, 2018; 
徐卫华等, 2021)。但由于非法捕杀、鱼类资源过度 开发、栖息地破坏等原因, 曾广泛分布于东北地区 的欧亚水獭种群数量持续下降(Zhang et al, 2016, 2018)。因此, 科学评估东北地区的水獭分布格局并 对其保护优先区进行识别可为未来水獭保护规划 的制定奠定基础。

本研究基于2016-2020年的调查数据, 使用组 合模型模拟了东北地区水獭的潜在分布区, 利用地 理信息系统和Zonation模型识别了水獭的保护优先 区并计算了各省区水獭面临的人类压力, 在此基础 上结合国家级自然保护区的空间布局评估了水獭 保护现状, 并以内蒙古森工集团、大兴安岭林业集 团、伊春森工集团为例分析了重点国有林区在水獭 保护中的作用, 以期为我国东北地区的水獭保护工 作提供科学支撑和依据。

\section{1 材料与方法}

\section{1 研究区域}

研究区地跨黑龙江、吉林、辽宁、内蒙古 4 个 省级行政区 $\left(38^{\circ} 42^{\prime}-53^{\circ} 17^{\prime} \mathrm{N}, 115^{\circ} 30^{\prime}-135^{\circ} 06^{\prime} \mathrm{E}\right)$ (图1)。该地区涵盖了中温带和寒温带, 分布有我国
最大的天然林区，主要山脉包括大兴安岭、小兴安 岭、张广才岭、完达山、长白山等, 海拔 $0-2,691 \mathrm{~m}$ 。 除了大面积的森林, 研究区内还分布着大面积的草 原和湿地生态系统。多样化的生态系统孕育了大量 的野生动植物, 如东北虎(Panthera tigris altaica)、 东北豹(P. pardus orientalis)、貂熊(Gulo gulo)、丹顶 鹤(Grus japonensis)等，使之成为全球同纬度生物 多样性最高的地区之一(吴征镒，1980; 赵正阶, 1999; 丁一汇, 2013)。

\section{2 数据收集}

为尽可能获得准确而全面的水獭分布数据, 研 究团队于2016-2020年通过访问调查、问卷调查、 野外实地调查、粪便收集、文献收集等多种方法共 获得水獭分布位点数据247个(附录1)。为降低空间 自相关对物种分布建模的影响, 本研究利用水獭的 最小家域对 $3 \mathrm{~km}$ 内的分布位点进行稀疏化处理, 即 $3 \mathrm{~km}$ 内的分布位点仅随机保留一个, 最终得到 231 个水獭分布点用于分布建模(图1) (Erlinge, 1967)。

环境变量的选择对于物种分布建模至关重要, 理想状态下应根据物种的生态学习性做出科学选 择(Williams et al, 2012; Braunisch et al, 2013)。本文

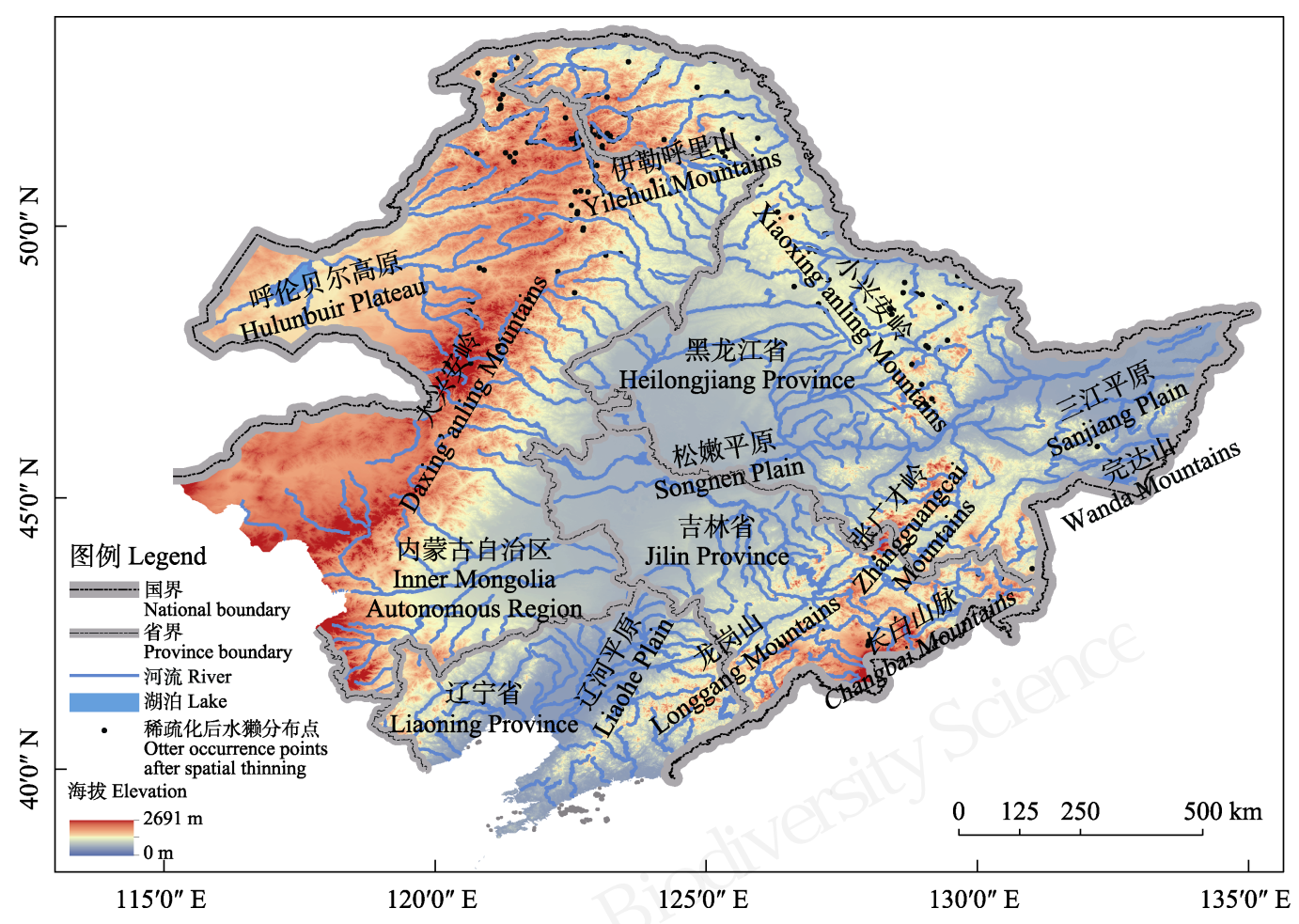

图1 中国东北地区稀疏化后水獭的231个分布位点

Fig. 1 A total of 231 occurrence points of otter after spatial thinning in Northeast China 
参考前人研究并结合水獭的生态学习性选择了 11 个环境因子用于水獭的分布建模 (Robitaille \& Laurence, 2002; Remonti et al, 2009; Cianfrani et al, 2011; Zhang et al, 2018), 包括: (1) 5 个与水相关的 环境变量, 分别是年降水量、最湿季降水量、最干 季降水量、距河流距离、湿润指数; (2) 2 个地形变 量, 分别是海拔和地表起伏度; (3) 1 个植被变量: 有林地密度; (4) 3 个人为影响变量, 分别是距道路 距离、人口密度和人类压力。其中年降水量、最湿 季降水量、最干季降水量下载自世界气候数据网站 (http://www.worldclim.org/); 距河流距离和距道路 距离数据来源于全国地理信息资源目录服务系统 (https://www.webmap.cn); 湿润指数下载自资源环 境科学与数据中心(http://www.resdc.cn); 海拔数据 下载自美国航天飞机雷达地形测绘数据(SRTM 90 $\mathrm{m}$ Digital Elevation Database); 地表起伏度下载自全 球变化科学研究数据出版系统(http://www.geodoi.ac. $\mathrm{cn}$ ); 有林地密度由资源环境科学与数据中心土地 利用类型数据提取计算得到(http://www.resdc.cn/De fault.aspx); 人口密度数据下载自资源环境科学与 数据中心(http://www.resdc.cn); 人类压力变量下载 自社会经济数据和应用中心(https:// sedac.ciesin.col umbia.edu/data/sets/browse), 这一变量由 13 种人类 对自然的压力数据模拟而来, 反映了人类对自然景 观的影响程度, 取值范围0-1 (Kennedy et al, 2019)。 所有环境变量均为连续性变量, 栅格大小统一定义 为 $30^{\prime \prime}$ (约 $\left.1 \mathrm{~km}\right)$ 。因环境因子的多重共线性会影响建
模的准确性, 本研究使用方差膨胀因子(variance inflation factor, VIF) 对所有环境变量进行预处理, 以降低变量之间的过度拟合 $(\mathrm{VIF}<10)$ (Dormann et al, 2013), 经过两次迭代运算最终笁选出 10 个环境 变量用于水獭分布建模(表1)。

\section{3 模型模拟}

使用R软件开发的BIOMOD2程序包对水獭的 分布状况进行模拟(Thuiller et al, 2009; Yang et al, 2021)。BIOMOD2包含 10 种模型，分别是广义线性 模型(GLM)、广义加法模型(GAM)、广义推进模型 $(\mathrm{GBM})$ 、分类树模型 $(\mathrm{CTA})$ 、人工神经网络模型 $(A N N)$ 、柔性判别分析(FDA)、表面分布区分室模 型 (SRE/BIOCLIM)、多元适应回归样条函数 (MARS)、随机森林 (RF) 和最大熵(MaxEnt)模型 (Thuiller et al, 2009; Zhang et al, 2020)。为提高建模 精度, 我们将道路 $30 \mathrm{~km}$ 设置为背景点偏差校正区, 生成 2,000 个背景点作为水獭的无分布数据, 并在 组合建模前使用真实技巧统计值(true skill statistics, TSS)和受试者操作特征曲线下的面积值(area under curve, AUC)对程序包内的 10 个模型进行评估，根据 模型评估标准选择TSS $>0.85$ 且AUC $>0.9$ 的算法 作为组合建模的最优算法(Hanley \& Mcneil, 1982; Allouche et al, 2006)。依据运算结果, 最终选择 GBM和RF用于水獭的分布模拟(图2)。本研究在建 模中随机选取 $70 \%$ 的数据作为训练样本, $30 \%$ 的数 据作为验证样本, 使用BIOMOD2程序包对建模算 法进行调参，重复迭代运算30次以降低结果的不确

表1 环境变量的方差膨胀因子(VIF)及重要性

Table 1 Variance inflation factor (VIF) value and importance of environmental variables

\begin{tabular}{llll}
\hline 环境变量 & 第一次方差膨胀因子评估 & 第二次方差膨胀因子评估 & 重要性 \\
Environmental variables & VIF evaluation for the first time & VIF evaluation for the second time & Importance \\
\hline 年降水量 Annual precipitation & 14.246 & - & - \\
最湿季降水量 Precipitation of wettest quarter & 6.432 & 2.815 & 0.017 \\
最干季降水量 Precipitation of driest quarter & 4.322 & 2.870 & 0.018 \\
距河流距离 Distance from river & 1.361 & 1.357 & 0.521 \\
湿润指数 Moisture index & 3.120 & 2.946 & 0.051 \\
海拔 Elevation & 7.402 & 7.078 & 0.006 \\
地表起伏度 Relief degree of land surface & 6.491 & 6.416 & 0.002 \\
有林地密度 Forest density & 2.732 & 2.429 & 0.02 \\
距道路距离 Distance from road & 1.389 & 1.376 & 0.003 \\
人口密度 Human density & 1.070 & 1.067 & 0.117 \\
人类压力 Anthropogenic pressures & 2.590 & 2.500 & 0.048 \\
\hline
\end{tabular}

年降水量被排除(VIF > 10) Annual precipitation was excluded by the VIF (VIF > 10) 


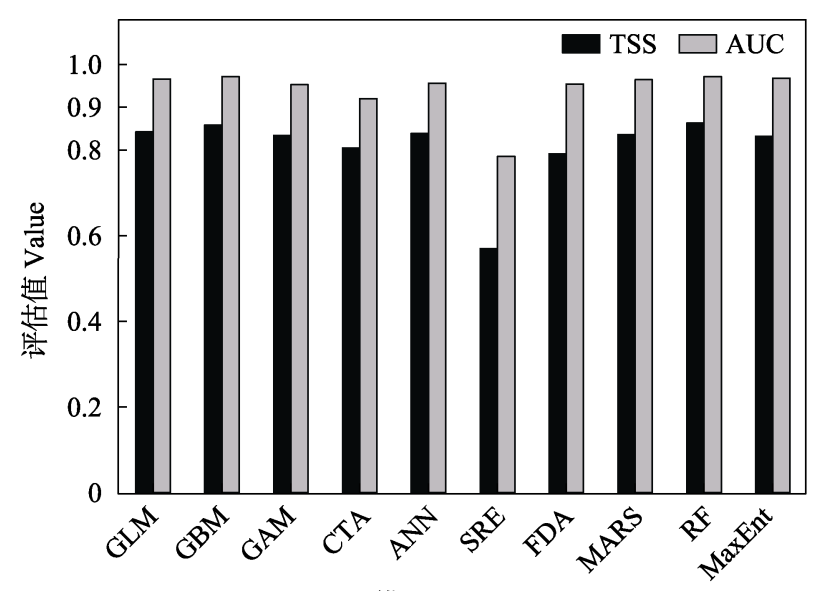

模型 Models

图2 模型选择标准(TSS: 真实技巧统计值; AUC: 受试者 操作特征曲线下的面积值)。GLM: 广义线性模型; GBM: 广义推进模型; GAM: 广义加法模型; CTA: 分类树模型; ANN: 人工神经网络模型; SRE: 表面分布区分室模型; FDA: 柔性判别分析; MARS: 多元适应回归样条函数; RF: 随机森林; MaxEnt: 最大熵模型。

Fig. 2 Models selection (TSS, True skill statistics; AUC, Area under the receiver operating characteristic curve). GLM, Generalized linear model; GBM, Generalized boosted regression model; GAM: Generalized additive model; CTA, Classification tree analysis; ANN, Artificial neural network; SRE, Surface range envelope; FDA, Flexible discriminant analysis; MARS, Multiple adaptive regression splines; RF: Random forest; MaxEnt, Maximum entropy.

定性，最后使用最大TSS作为切分阈值将生境适宜 度图转化为分布/不分布的二值图(Thuiller et al, 2009; 张晓玲等, 2019; Yang et al, 2021)。

\section{4 保护优先区识别}

本文使用热点分析 (hot spot analysis) 和 Zonation模型进行水獭保护优先区的识别。热点分 析既可以探测研究区内具有显著统计学意义的局 部热点区域, 也可以在一定程度上削弱物种分布模 型模拟结果的不确定性，最终为保护优先区识别、 自然保护地规划及保护决策制定提供支持(马克平,
2001; Li et al, 2017; 庄鸿飞等, 2018)。Zonation模型 通过逐个移除保护价值最低的栅格, 最终得到一个 高连通性的保护优先区排序(Moilanen et al. 2005; Moilanen, 2007)。鉴于 $\mathrm{Gi}^{*}$ 系数在空间聚类统计中的 优越性(张松林和张昆, 2007), 本研究使用ArcGIS 10.2.2 的Getis-Ord Gi ${ }^{*}$ 空间统计工具进行热点分析, 将极显著热点区域 $\left(\mathrm{Gi}^{*}\right.$ 统计量 > 2.58, 置信度 $\left.99 \%\right)$ 作为水獭的热点分布区。随后将这一热点区域作为 Zonation程序运行的输入文件, 采用核心区域法 (core area zonation)以保留适宜度较高的规划单元, 并选择边缘移除规则(rule of edge removal)以保持 景观的连通性。考虑到未来的管理成本问题, 本研 究使用人口密度作为Zonation模型运算的成本图层, 设置尧曲因子为“ 1 ” 以保证运行结果的最优化。最终 将计算结果按保护价值的高低分为一级优先区 ( $>$ $60 \%)$ 、二级优先区 $(20 \%-60 \%)$ 和三级优先区 $(<$ $20 \%$ )。

以上数据分析在 ArcGIS 10.2.2、R 3.4.3、 Zonation 4.00、Excel 2018和SPSS 20.0中实现。

\section{2 结果}

\section{1 模型表现和重要环境因子}

使用 $\mathrm{GBM}$ 和 RF 组合建模后的平均 TSS 值达 0.962, AUC值达0.997, 模型预测精度极高。组合模 型的输出结果表明, 距河流距离和人口密度是影响 水獭分布最重要的因子(表1), 响应曲线见附录2。

\section{2 潜在分布区和保护优先区}

物种分布建模的结果表明，水獭潜在分布区面 积约为 $104,515.04 \mathrm{~km}^{2}$, 其中内蒙古自治区占 $48.32 \%$; 黑龙江省占 $46.44 \%$; 吉林省占 $5.02 \%$; 辽 宁省仅占 $0.22 \%$ (表 2, 图3)。Zonation模型的保护优 先性分析结果显示, 除三级优先区分布于研究区各

表2 东北各省/自治区水獭潜在分布区和保护优先区面积及平均人类压力

Table 2 Potential distribution and conservation priority areas of the otter and mean anthropogenic pressures in each provinces/ autonomous region

\begin{tabular}{lllll}
\hline & $\begin{array}{l}\text { 潜在分布区面积 } \\
\text { Potential distribution } \\
\left(\mathrm{km}^{2}\right)\end{array}$ & $\begin{array}{l}\text { 保护优先区面积 } \\
\text { Conservation priority } \\
\text { areas }\left(\mathrm{km}^{2}\right)\end{array}$ & $\begin{array}{l}\text { 潜在分布区平均人类压力 } \\
\text { Mean anthropogenic pressures } \\
\text { of potential distribution }(0-1)\end{array}$ & $\begin{array}{l}\text { 保护优先区平均人类压力 } \\
\text { Mean anthropogenic pressures of } \\
\text { conservation priority areas }(0-1)\end{array}$ \\
\hline 内蒙古 Inner Mongolia & $50,503.58$ & $30,613.58$ & 0.063 & 0.045 \\
黑龙江 Heilongjiang & $48,533.40$ & $10,269.55$ & 0.078 & 0.065 \\
吉林 Jilin & $5,250.36$ & $4,338.16$ & 0.148 & 0.135 \\
辽宁 Liaoning & 227.7 & 227.7 & 0.223 & 0.223 \\
\hline
\end{tabular}




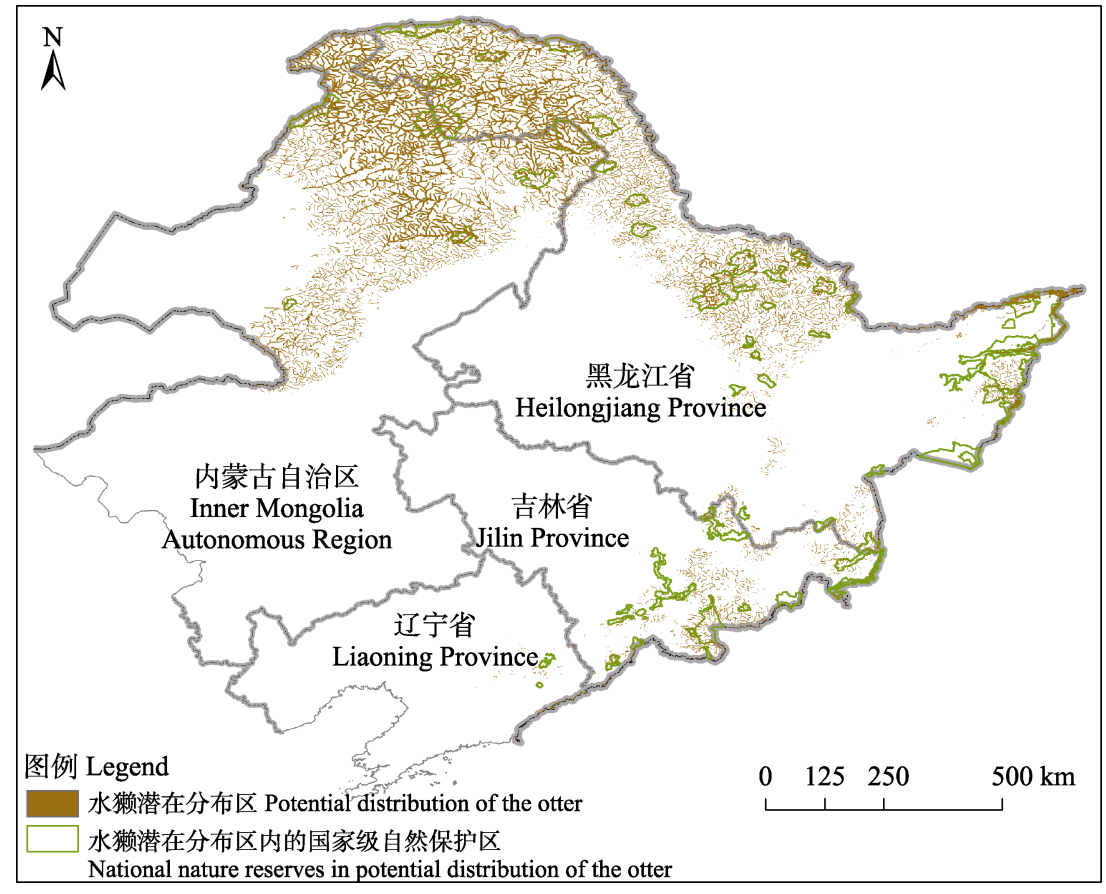

图3 东北地区水獭潜在分布区和保护现状

Fig. 3 Potential distribution and conservation status of the otter in Northeast China

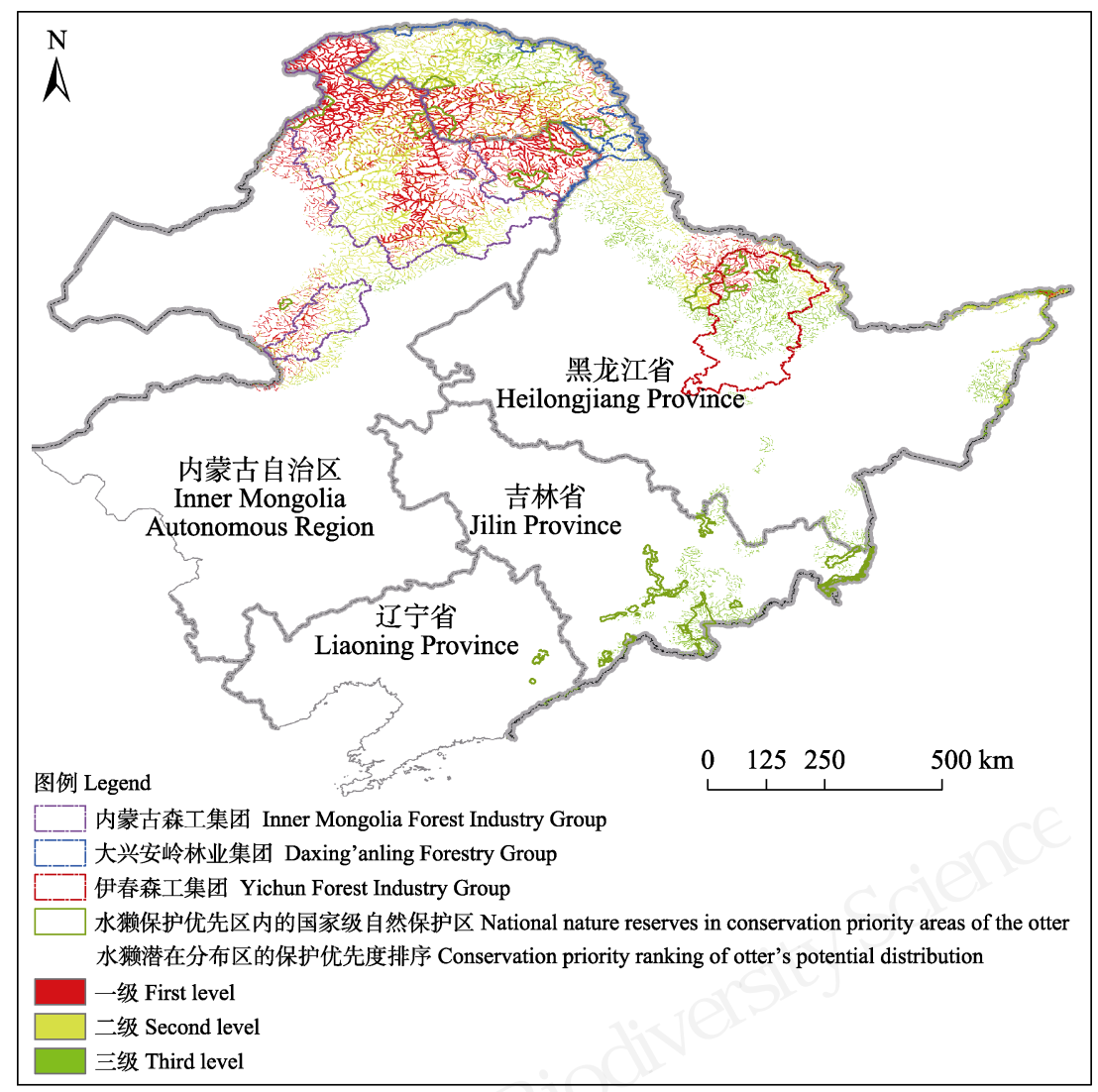

图4 水獭保护优先度排序和保护优先区保护现状

Fig. 4 Conservation priority ranking and conservation status in conservation priority areas of the otter 
省外，一级、二级优先区全部位于内蒙古和黑龙江 (图4)。综合考虑保护成本及水獭在各省/自治区的 分布情况, 本研究将内蒙古和黑龙江的水獭保护价 值最高的一级优先区、吉林的三级优先区及辽宁的 全部水獭潜在分布区作为保护优先区。保护优先区 面积约为 $45,448.99 \mathrm{~km}^{2}$, 占水獭潜在分布区的 $43.49 \%$, 主要集中于大兴安岭北部林区腹地、小兴 安岭中部、三江平原靠近黑龙江和乌苏里江江边、 长白山腹地及辽宁省鸭绿江流域, 行政上隶属内蒙 古兴安盟、呼伦贝尔市, 黑龙江大兴安岭地区、黑 河市、伊春市、佳木斯市, 吉林省延边州、白山市, 辽宁省本溪市和丹东市。使用人类压力图层评估了 水獭潜在分布区和保护优先区在各省区面临的人 类压力, 其大小依次为: 辽宁 $>$ 吉林 $>$ 黑龙江 > 内蒙古(表2，图5)。

\section{3 区域保护现状}

鉴于国家级自然保护区在生物多样性保育中 的特殊地位并考虑其他类型保护地数据的准确性, 本研究对水獭保护现状的分析仅考虑了国家级自 然保护区。叠加分析结果表明, 研究区内 110 个国家 级自然保护区中共有 63 个包含水獭的潜在分布区, 覆盖面积约12,168.93 $\mathrm{km}^{2}$, 占水獭潜在分布区面积 的11.64\% (图3, 附录3)。其中32个国家级自然保护 区包含水獭的保护优先区，覆盖面积约 4,946.99 $\mathrm{km}^{2}$, 占水獭保护优先区的 $10.88 \%$ (图4, 附录4)。而 作为重点国有林区的所在地, 内蒙古森工集团、大
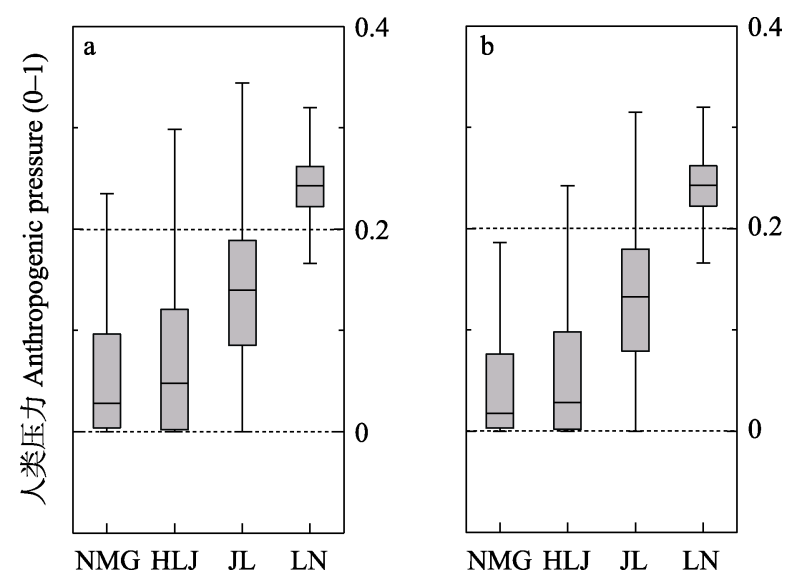

图5 水獭潜在分布区(a)和保护优先区(b)面临的人类压力。 NMG: 内蒙古; HLJ: 黑龙江; JL: 吉林; LN: 辽宁。

Fig. 5 Anthropogenic pressures in potential distribution (a) and conservation priority areas (b) of the otter. NMG: Inner Mongolia; HLJ: Heilongjiang; JL: Jilin; LN: Liaoning.
兴安岭林业集团、伊春森工集团所辖林区覆盖的水 獭潜在分布区达 $74,390.89 \mathrm{~km}^{2}$, 保护优先区达 $36,022.22 \mathrm{~km}^{2}$, 分别占水獭潜在分布区和保护优先 区面积的 $71.18 \%$ 和 $79.26 \%$ (图4), 因此重点国有林 区亦应作为水獭保护体系构建的重要组成部分。

\section{3 讨论}

\section{1 物种分布建模}

准确的物种分布数据是进行物种分布建模的 重要基础。对水獭而言, 由于缺乏专项调查, 同时 因其不在林草部门负责的全国陆生野生动物资源 调查名单中，因而准确的分布信息极其稀少，有研 究表明, 2000年后全国仅有57个确认的水獭分布点 (Zhang et al, 2018)。为尽可能获取准确而又全面的 分布信息, 本研究团队自2016年开始先后赴黑龙 江、松花江、乌苏里江沿岸，小兴安岭林区、大兴 安岭林区、吉林省开展调查, 本研究建模使用的水 獭分布数据约 $85 \%$ 来源于实地野外调查或访谈调查, 极少数没有调查又基本确认有水獭分布的地区补 充使用了文献资料。此外, 本研究从环境变量选择、 模型选择等多方面着手降低建模结果的不确定性, 预测结果能较大程度地反映水獭的真实分布。

\section{2 致危因素及保护优先性}

明确物种的濒危机制是精准施策的关键(Yang et al, 2021)。根据环境变量重要性排序, 距河流距离 和人口密度是影响水獭分布最重要的因子, 与前人 研究结果类似, 维持高质量的河流并降低人为干扰 是水獭保护的关键抓手(Prenda et al, 2001; 雷伟和 李玉春, 2008)。本研究表明水獭主要集中分布于人 口密度较低的河流上游, 如大兴安岭的根河、图里 河、诺敏河、激流河、盘古河、呼玛河等; 小兴安 岭的逊别拉河、公别拉河、库尔滨河、嘉荫河等; 长 白山的头道白河、二道白河、漫江等。相比河流下 游, 这些地区人烟稀少, 受人类干扰程度低, 很可 能成为野生水獭种群最先复壮的区域。从保护优先 性来看, 大兴安岭林区水獭保护优先区集中连片, 同时与伊春林区的保护优先区通过黑河市的法别 拉河、公别拉河、逊别拉河相连, 总体来说此区域 水獭分布较为集中, 种群之间没有明显的地理隔离, 并且这些区域面临的人类压力也较小, 因而是维持 东北地区水獭种群稳定的重中之重。三江平原地区 
是国家重要的商品粮生产基地, 在强烈的人类干扰 下, 水獭现已退缩于三江国家级自然保护区、黑瞎 子岛国家级自然保护区等靠近中俄边境的几个保 护区内。吉林的水獭种群与三江平原类似, 保护优 先区大多位于靠近边境的自然保护区。辽宁省水獭 栖息地面临的人类压力最大, 保护优先性分析的结 果表明仅有极小面积的三级优先区分布于靠近朝 鲜边境的鸭绿江流域(图4), 因此本研究将其全部的 潜在分布区纳入保护优先区以实现对潜在残留种 群的保护。

\section{3 区域保护现状}

截至2017年底, 东北地区仅国家级自然保护地 就达594处(张芳玲等, 2020), 这些保护地构成了我 国东北地区的物种基因库和生态保护的基本构架。

其中内蒙古森工集团下辖的根河森工公司依托根 河源国家湿地公园建设了水獭自然保护小区, 这也 是为数不多的以水獭为主要保护对象而设立的自 然保护地。尽管国家级自然保护区仅占水獭潜在分 布区面积的 $11.64 \%$, 但在天然林全面禁伐的背景下, 重点国有林区可能在未来东北地区生物多样性保 护中发挥更大的作用, 研究发现水獭 $70 \%$ 以上的潜 在分布区和近 $80 \%$ 的保护优先区位于国有森工集团 的所辖林区 (未包括龙江森工、吉林森工和长白山森 工)。森工集团应进一步履行其野生动植物保护职能, 严格遵照《野生动物保护法》《野生植物保护条例》

《陆生野生动物保护实施条例》等法律条令, 全面 保护辖区内的野生动植物。国有林区具有生态区位 重要、生态系统完整性强、权属清晰、管理体制健 全的特点(庞晓峰, 2018; 唐芳林等, 2018), 根据《国 家公园设立规范》(GB/T 39737-2020)中国家公园的 准入条件, 重点国有林区具有建设国家公园的天然 优势。鉴于此, 本研究建议将重点国有林区中具有 重要保护价值的区域逐步纳入以国家公园为主体 的自然保护地体系中, 以实现生物多样性的系统性 和完整性保护。

\section{4 不足之处和保护建议}

受限于河流水质、鱼类资源丰富度、盗猎威胁 强弱等影响, 水獭种群数量和分布数据难以在短期 内准确获得, 本研究识别的保护优先区也具有一定 的局限性, 未来需进一步补充数据以构建更具指导 意义的水獭保护规划。尤其是水獭栖息地面临较大
人类压力的吉林省和辽宁省, 将是下一步亟待进行 更深入保护生物学研究的重点区域。

相比其他珍稀濒危物种, 水獭不仅繁殖力强且 对环境的适应力强, 纬度、海拔、栖息地大小等均 不是影响其分布的限制因子, 因而其种群复壮潜力 巨大(徐龙辉, 1984; Roos et al, 2015)。2016年12月， 中共中央办公厅、国务院办公厅印发了《关于全面 推行河长制的意见》，将水生生态系统的保护提升 到新的战略高度, 这为实现水獭的全流域系统保护 奠定了基础(陈雷, 2016)。在我们的访谈调查中也获 悉, 近年来水獭的活动踪迹逐年增多, 部分地区的 渔业生产已经受到水獭的影响, 但这一过程往往也 伴随着渔网等捕鱼工具的误杀, 因此我们建议在各 级河长协调下, 渔业和林业部门要重点协调好保护 优先区内人民生产生活与野生动物保护的关系。为 实现水獭种群的恢复, 我们基于实地调查和研究结 果提出以下建议: (1)加强对河流污染物的管理, 禁 止在水獭栖息地排放农药、杀虫剂、工业废料等污 染物; (2)控制渔民捕鱼强度，严格取缔非法捕鱼等 活动, 科学设立禁渔期; (3)开展全面的水獭专项调 查并建立长期监测体系, 系统掌握其种群变化情况; (4)加大对水獭科研方面的投入, 以指导水獭保护工 作; (5)加强水獭保护宣传力度, 提升公众保护意识。

致谢: 感谢内蒙古森工集团、呼伦贝尔市林草局、 黑龙江省林草局、大兴安岭林业集团、黑河林草局、 伊春森工集团、佳木斯林草局、吉林省林草局等单 位对调查研究工作的大力支持。

\section{参考文献}

Allouche O, Tsoar A, Kadmon R (2006) Assessing the accuracy of species distribution models: Prevalence, kappa and the true skill statistic (TSS). Journal of Applied Ecology, 43, 1223-1232.

Braunisch V, Coppes J, Arlettaz R, Suchant R, Schmid H, Bollmann K (2013) Selecting from correlated climate variables: A major source of uncertainty for predicting species distributions under climate change. Ecography, 36, 971-983.

Chen L (2016) The implementation of the concept of green development and full implementation of the River Chief System management model. Guangdong Water Resources and Hydropower, (12), 2-3. (in Chinese) [陈雷 (2016) 落 实绿色发展理念, 全面推行河长制河湖管理模式. 广东 
水利水电, (12), 2-3.]

Cianfrani C, Lay GL, Maiorano L, Satizábal HF, Loy A, Guisan A (2011) Adapting global conservation strategies to climate change at the European scale: The otter as a flagship species. Biological Conservation, 144, 2068-2080.

Ding YH (2013) China's Climate. Science Press, Beijing. (in Chinese) [丁一汇 (2013) 中国气候. 科学出版社, 北京.]

Dormann CF, Elith J, Bacher S, Buchmann C, Carl G, Carré G, Marquéz JRG, Gruber B, Lafourcade B, Leitão PJ, Münkemüller T, McClean C, Osborne PE, Reineking B, Schröder B, Skidmore AK, Zurell D, Lautenbach S (2013) Collinearity: A review of methods to deal with it and a simulation study evaluating their performance. Ecography, $36,27-46$.

Erlinge S (1967) Home range of the otter Lutra lutra L. in Southern Sweden. Oikos, 18, 186-209.

Gomez L, Leupen B, Theng M, Fernandez K, Savage M (2016) Illegal Otter Trade: An Analysis of Seizures in Selected Asian Countries (1980-2015). Traffic Report, Malaysia.

Guisan A, Tingley R, Baumgartner JB, Naujokaitis-Lewis I, Sutcliffe PR, Tulloch AIT, Regan TJ, Brotons L, McDonald-Madden E, Mantyka-Pringle C, Martin TG, Rhodes JR, Maggini R, Setterfield SA, Elith J, Schwartz MW, Wintle BA, Broennimann O, Austin M, Ferrier S, Kearney MR, Possingham HP, Buckley YM (2013) Predicting species distributions for conservation decisions. Ecology Letters, 16, 1424-1435.

Hanley JA, McNeil BJ (1982) The meaning and use of the area under a receiver operating characteristic (ROC) curve. Radiology, 143, 29-36.

Hao ZQ, Wang QL, Dai LM (1998) The importance of the national programme for natural forests conservation on biodiversity conservation in northeast State-owned forest areas of China. In: Biodiversity Conservation in China in the 21st Century: Proceedings of the Third National Symposium on Biodiversity Conservation and Sustainable Utilization (ed. Xu ZH), pp. 21-26. China Forestry Publishing House, Beijing. (in Chinese with English abstract) [郝占庆, 王庆 礼，代力民 (1998) 天然林保护工程在东北林区生物多 样性保护中的意义. 见: 面向21世纪的中国生物多样性 保护: 第三届全国生物多样性保护与持续利用研讨会论 文集(许智宏主编), 21-26页. 中国林业出版社, 北京.]

Hu YS, Luo ZH, Chapman CA, Pimm SL, Turvey ST, Lawes MJ, Peres CA, Lee TM, Fan PF (2019) Regional scientific research benefits threatened-species conservation. National Science Review, 6, 1076-1079.

Huang BR, Ma YH, Huang K, Su LY, Zhang CL, Cheng DW, Wang Y (2018) Strategic approach on promoting reform of China's natural protected areas system with national parks as backbone. Bulletin of Chinese Academy of Sciences, 33, 1342-1351. (in Chinese with English abstract) [黄宝荣, 马
永欢, 黄凯, 苏利阳, 张从林, 程多威, 王毅 (2018) 推 动以国家公园为主体的自然保护地体系改革的思考. 中 国科学院院刊, 33, 1342-1351.]

Kennedy CM, Oakleaf JR, Theobald DM, Baruch - Mordo S, Kiesecker J (2019) Managing the middle: A shift in conservation priorities based on the global human modification gradient. Global Change Biology, 25, 811-826.

Kruuk H (2006) Otters: Ecology, Behaviour and Conservation. Oxford University Press, New York.

Lei W, Li YC (2008) Study and conservation status of otters. Journal of Biology, 25, 47-50. (in Chinese with English abstract) [雷伟, 李玉春 (2008) 水獭的研究与保护现状. 生物学杂志, 25, 47-50.]

Li F, Chan BPL (2018) Past and present: The status and distribution of otters (Carnivora: Lutrinae) in China. Oryx, 52, 619-626.

Li YJ, Zhang LW, Yan JP, Wang PT, Hu NK, Cheng W, Fu BJ (2017) Mapping the hotspots and coldspots of ecosystem services in conservation priority setting. Journal of Geographical Sciences, 27, 681-696.

Liu HL, Huang JY (2015) How to promote the reform of state-owned forestry-Zhao Shucong, director of the State Forestry Administration, interpreted the Reform Plan of State-owned Forest Farm and the Guiding Opinions on the Reform of State-owned Forest Areas. Country Agriculture Farmers (A), (4), 11-12. (in Chinese) [刘惠兰, 黄俊毅 (2015) 国有林业改革如何扎实推进一一国家林业局局长 赵树从解读《国有林场改革方案》和《国有林区改革指 导意见》。农村·农业·农民(A版), (4), 11-12.]

Ma KP (2001) Hotspots assessment and conservation priorities identification of biodiversity in China should be emphasized. Acta Phytoecologica Sinica, 25, 125-126. (in Chinese) [马克平 (2001) 中国生物多样性热点地区 (Hotspot)评估与优先保护重点的确定应该重视. 植物生 态学报, 25, 125-126.]

Mason CF, MacDonald SM (1986) Otters: Ecology and Conservation. Cambridge University Press, Cambridge.

Moilanen A (2007) Landscape Zonation, benefit functions and target-based planning: Unifying reserve selection strategies. Biological Conservation, 134, 571-579.

Moilanen, A, Franco AMA, Early RI, Fox R, Wintle B, Thomas CD (2005) Prioritizing multiple-use landscapes for conservation: Methods for large multi-species planning problems. Proceedings of the Royal Society B: Biological Sciences, 272, 1885-1891.

Pang XF (2018) Thoughts on the establishment of national park in the north of Inner Mongolia Greater Khingan forest district. Inner Mongolia Forestry Investigation and Design, 41(4), 73-75. (in Chinese) [庞晓峰 (2018) 关于内蒙古大 兴安岭林区北部原始林区建立国家公园的思考. 内蒙古 林业调查设计, 41(4), 73-75.] 
Piao ZJ, Sui YC, Wang Q, Li Z, Niu LJ (2011) Population fluctuation and resource protection of otter (Lutra lutra) in Changbai Mountain Nature Reserve. Journal of Hydroecology, 32, 115-120. (in Chinese with English abstract) [朴正吉 (2011) 长白山自然保护区水獭种群数 量变动与资源保护. 水生态学杂志, 32, 115-120.]

Prenda J, López-Nieves P, Bravo R (2001) Conservation of otter (Lutra lutra) in a Mediterranean area: The importance of habitat quality and temporal variation in water availability. Aquatic Conservation: Marine and Freshwater Ecosystems, 11, 343-355.

Remonti L, Balestrieri A, Prigioni C (2009) Altitudinal gradient of Eurasian otter (Lutra lutra) food niche in Mediterranean habitats. Canadian Journal of Zoology, 87, 285-291.

Robitaille JF, Laurence S (2002) Otter, Lutra lutra, occurrence in Europe and in France in relation to landscape characteristics. Animal Conservation, 5, 337-344.

Roos A, Loy A, de Silva P, Hajkova P, Zemanová B (2015) Lutra lutra. The IUCN Red List of Threatened Species 2015. https://www.iucnredlist.org/species/12419/21935287. (accessed on 2014-6-20)

Tang FL, Wang MJ, Sun HY (2018) Analysis on establishing the protected area system dominated by national park. Forestry Construction, (1), 1-5. (in Chinese with English abstract) [唐芳林, 王梦君, 孙鸿雁 (2018) 建立以国家公 园为主体的自然保护地体系的探讨. 林业建设, (1), 1-5.]

Tang XP, Jiang YF, Liu ZL, Chen JZ, Liang BK, Lin C (2019) Top-level design of the natural protected area system in China. Forest Resources Management, (3), 1-7. (in Chinese with English abstract) [唐小平, 蒋亚芳, 刘增力, 陈君帜, 梁兵宽, 萄琛 (2019) 中国自然保护地体系的顶层设计. 林业资源管理, (3), 1-7.]

Thuiller W, Lafourcade B, Engler R, Araújo MB (2009) BIOMOD - A platform for ensemble forecasting of species distributions. Ecography, 32, 369-373.

Williams KJ, Belbin L, Austin MP, Stein JL, Ferrier S (2012) Which environmental variables should I use in my biodiversity model? International Journal of Geographical Information Science, 26, 2009-2047.

Wu ZY (1980) China's Vegetation. Science Press, Beijing. (in Chinese) [吴征镒 (1980) 中国植被. 科学出版社, 北京.]

$\mathrm{Xu}$ LH (1984) Species of otters in China and the conservation of their natural resources. Chinese Wildlife, 5(1), 9-11. (in Chinese with English abstract) [徐龙辉 (1984) 中国水獭 种类及资源保护. 野生动物, 5(1), 9-11.]

Xu WH, Zang ZH, Du A, Ouyang ZY (2021) The experiences of Northeast China Tiger and Leopard National Park pilot. Biodiversity Science, 29, 295-297. (in Chinese) [徐卫华, 藏振华, 杜傲, 欧阳志云 (2021) 东北虎豹国家公园试点 经验. 生物多样性, 29, 295-297.]
Yang L, Shi KC, Ma C, Ren GP, Fan PF (2021) Mechanisms underlying altitudinal and horizontal range contraction: The western black crested gibbon. Journal of Biogeography, 48, 321-331.

Zhang C, Yang L, Wu SH, Xia WC, Yang L, Li MM, Chen MH, Luan XF (2020) Use of historical data to improve conservation of the black grouse (Lyrurus tetrix) in Northeast China. Ecosphere, 11, e03090.

Zhang FL, Pu Z, Liang XY, Gu YY, Xing SH (2020) The quantitative characteristics of natural protected areas in Northeast China. Journal of Beijing Forestry University, 42(2), 61-67. (in Chinese with English abstract) [张芳玲, 蒲真, 梁晓玉, 古元阳, 邢韶华 (2020) 中国东北地区自 然保护地数量特征分析. 北京林业大学学报, 42(2), 61-67.]

Zhang L, Wang QY, Yang L, Li F, Chan BPL, Xiao ZS, Li S, Song DZ, Piao ZJ, Fan PF (2018) The neglected otters in China: Distribution change in the past 400 years and current conservation status. Biological Conservation, 228, 259-267.

Zhang R, Yang L, Laguardia A, Jiang Z, Huang MJ, Lü J, Ren YH, Zhang W, Luan XF (2016) Historical distribution of the otter (Lutra lutra) in north-east China according to historical records (1950-2014). Aquatic Conservation: Marine and Freshwater Ecosystems, 26, 602-606.

Zhang SL, Zhang K (2007) Contrast study on Moran and Getis-ord indexes of local spatial autocorrelation indices. Journal of Geodesy and Geodynamics, 27(3), 31-34. (in Chinese with English abstract) [张松林, 张昆 (2007) 空间 自相关局部指标Moran指数和 $\mathrm{G}$ 系数研究. 大地测量与地 球动力学, 27(3), 31-34.]

Zhang XL, Li YC, Wang YY, Cai HY, Zeng H, Wang ZH (2019) Influence of future climate change in suitable habitats of tea in different countries. Biodiversity Science, 27, 595-606. (in Chinese with English abstract) [张晓玲, 李亦超, 王芸芸, 蔡宏宇, 曾辉, 王志恒 (2019) 未来气 候变化对不同国家茶适宜分布区的影响. 生物多样性, 27, 595-606.]

Zhao ZJ (1999) Zoography of Rare and Endangered Species in Northeast China. China Forestry Publishing House, Beijing. (in Chinese with) [赵正阶 (1999) 中国东北地区珍稀濒危 动物志. 中国林业出版社, 北京.]

Zhuang HF, Zhang YB, Wang W, Ren YH, Liu FZ, Du JH, Zhou Y (2018) Optimized hot spot analysis for probability of species distribution under different spatial scales based on MaxEnt model: Manglietia insignis case. Biodiversity Science, 26, 931-940. (in Chinese with English abstract) [庄 鸿飞, 张殷波, 王伟, 任月恒, 刘方正, 杜金鸿, 周越 (2018) 基于最大熵模型的不同尺度物种分布概率优化热 点分析：以红色木莲为例. 生物多样性, 26, 931-940.]

(责任编委: 乔慧捷 责任编辑: 黄祥忠) 


\section{附录 Supplementary Material}

附录1 水獭分布位点信息

Appendix 1 The coordinate of otter occurrence

https://www.biodiversity-science.net/fileup/PDF/2021157-1.pdf

附录2 水獭适应性对重要变量的响应曲线

Appendix 2 Response curves of suitability of otter to important variables https://www.biodiversity-science.net/fileup/PDF/2021157-2.pdf

附录3 水獭潜在分布区内的国家级自然保护区

Appendix 3 National nature reserves in potential distribution of the otter https://www.biodiversity-science.net/fileup/PDF/2021157-3.pdf

附录4 水獭保护优先区内的国家级自然保护区

Appendix 4 National nature reserves in conservation priority areas of the otter https://www.biodiversity-science.net/fileup/PDF/2021157-4.pdf 
张超, 陈敏豪, 杨立, 庄鸿飞, 武曙红, 湛振杰, 王嘉栋, 奕晓峰 (2022) 东北地区水獭分布格局与保护优先区识别. 生物多 样性, 30, 21157. http://www.biodiversity-science.net/CN/10.17520/biods.2021157

附录1 水獭分布位点信息

Appendix 1 The coordinate of otter occurrence

\begin{tabular}{|c|c|c|c|c|}
\hline 编号 ID & 经度 Longitude $\left({ }^{\circ} \mathrm{E}\right)$ & 纬度 Latitude $\left({ }^{\circ} \mathrm{N}\right)$ & 数据来源 Sources & 位置 Location \\
\hline 1 & 125.63 & 52.04 & 实地访问调查 & 黑龙江省/大兴安岭地区/呼玛县 \\
\hline 2 & 125.67 & 52.03 & 实地访问调查 & 黑龙江省/大兴安岭地区/呼玛县 \\
\hline 3 & 125.95 & 51.63 & 电话访谈 & 黑龙江省/大兴安岭地区/呼玛县 \\
\hline 4 & 123.56 & 52.07 & 实地访问调查 & 黑龙江省/大兴安岭地区/呼中区 \\
\hline 5 & 123.61 & 51.99 & 实地访问调查 & 黑龙江省/大兴安岭地区/呼中区 \\
\hline 6 & 122.91 & 51.86 & 实地访问调查 & 黑龙江省/大兴安岭地区/呼中区 \\
\hline 7 & 123.01 & 51.77 & 实地访问调查 & 黑龙江省/大兴安岭地区/呼中区 \\
\hline 8 & 123.21 & 51.59 & 实地访问调查 & 黑龙江省/大兴安岭地区/呼中区 \\
\hline 9 & 123.51 & 52.07 & 实地访问调查 & 黑龙江省/大兴安岭地区/呼中区 \\
\hline 10 & 123.75 & 52.18 & 实地访问调查 & 黑龙江省/大兴安岭地区/呼中区 \\
\hline 11 & 123.48 & 52.08 & 实地访问调查 & 黑龙江省/大兴安岭地区/呼中区 \\
\hline 12 & 123.40 & 51.64 & 粪便采集 & 黑龙江省/大兴安岭地区/呼中区 \\
\hline 13 & 123.29 & 51.58 & 实地访问调查 & 黑龙江省/大兴安岭地区/呼中区 \\
\hline 14 & 122.86 & 51.79 & 电话访谈 & 黑龙江省/大兴安岭地区/呼中区 \\
\hline 15 & 123.02 & 51.75 & 电话访谈 & 黑龙江省/大兴安岭地区/呼中区 \\
\hline 16 & 122.87 & 51.71 & 电话访谈 & 黑龙江省/大兴安岭地区/呼中区 \\
\hline 17 & 122.89 & 51.67 & 电话访谈 & 黑龙江省/大兴安岭地区/呼中区 \\
\hline 18 & 123.04 & 51.67 & 电话访谈 & 黑龙江省/大兴安岭地区/呼中区 \\
\hline 19 & 123.18 & 51.72 & 电话访谈 & 黑龙江省/大兴安岭地区/呼中区 \\
\hline 20 & 123.23 & 51.67 & 电话访谈 & 黑龙江省/大兴安岭地区/呼中区 \\
\hline 21 & 123.23 & 51.61 & 电话访谈 & 黑龙江省/大兴安岭地区/呼中区 \\
\hline 22 & 123.08 & 51.49 & 电话访谈 & 黑龙江省/大兴安岭地区/呼中区 \\
\hline 23 & 123.00 & 51.42 & 电话访谈 & 黑龙江省/大兴安岭地区/呼中区 \\
\hline 24 & 123.09 & 51.42 & 电话访谈 & 黑龙江省/大兴安岭地区/呼中区 \\
\hline 25 & 122.93 & 51.69 & 电话访谈 & 黑龙江省/大兴安岭地区/呼中区 \\
\hline 26 & 122.87 & 53.46 & 实地访问调查 & 黑龙江省/大兴安岭地区/漠河市 \\
\hline 27 & 122.55 & 53.22 & 实地访问调查 & 黑龙江省/大兴安岭地区/漠河市 \\
\hline 28 & 122.95 & 53.33 & 实地访问调查 & 黑龙江省/大兴安岭地区/漠河市 \\
\hline 29 & 123.23 & 53.33 & 实地访问调查 & 黑龙江省/大兴安岭地区/漠河市 \\
\hline 30 & 122.75 & 52.92 & 实地访问调查 & 黑龙江省/大兴安岭地区/漠河市 \\
\hline 31 & 122.83 & 52.41 & 文献记载 & 黑龙江省/大兴安岭地区/漠河市 \\
\hline 32 & 123.01 & 52.45 & 文献记载 & 黑龙江省/大兴安岭地区/漠河市 \\
\hline 33 & 121.75 & 52.62 & 电话访谈 & 黑龙江省/大兴安岭地区/漠河市 \\
\hline 34 & 121.76 & 52.77 & 电话访谈 & 黑龙江省/大兴安岭地区/漠河市 \\
\hline 35 & 123.55 & 53.41 & 电话访谈 & 黑龙江省/大兴安岭地区/漠河市 \\
\hline 36 & 122.48 & 53.17 & 文献记载 & 黑龙江省/大兴安岭地区/漠河市 \\
\hline 37 & 123.56 & 53.04 & 电话访谈 & 黑龙江省/大兴安岭地区/漠河市 \\
\hline 38 & 122.79 & 52.41 & 文献记载 & 黑龙江省/大兴安岭地区/漠河市 \\
\hline 39 & 123.17 & 52.39 & 文献记载 & 黑龙江省/大兴安岭地区/漠河市 \\
\hline 40 & 124.08 & 52.85 & 实地访问调查 & 黑龙江省/大兴安岭地区/塔河县 \\
\hline 41 & 124.92 & 52.38 & 实地访问调查 & 黑龙江省/大兴安岭地区/塔河县 \\
\hline 42 & 124.11 & 52.96 & 实地访问调查 & 黑龙江省/大兴安岭地区/塔河县 \\
\hline 43 & 125.38 & 52.48 & 实地访问调查 & 黑龙江省/大兴安岭地区/塔河县 \\
\hline 44 & 125.63 & 52.89 & 实地访问调查 & 黑龙江省/大兴安岭地区/塔河县 \\
\hline 45 & 123.97 & 52.80 & 实地访问调查 & 黑龙江省/大兴安岭地区/塔河县 \\
\hline 46 & 123.86 & 52.68 & 实地访问调查 & 黑龙江省/大兴安岭地区/塔河县 \\
\hline 47 & 124.04 & 52.83 & 实地访问调查 & 黑龙江省/大兴安岭地区/塔河县 \\
\hline 48 & 125.18 & 53.18 & 实地访问调查 & 黑龙江省/大兴安岭地区/塔河县 \\
\hline
\end{tabular}


张超, 陈敏豪, 杨立, 庄鸿飞, 武曙红, 湛振杰, 王嘉栋, 亱晓峰 (2022) 东北地区水獭分布格局与保护优先区识别. 生物多 样性, 30, 21157. http://www.biodiversity-science.net/CN/10.17520/biods.2021157

\begin{tabular}{|c|c|c|c|c|}
\hline 编号 ID & 经度 Longitude $\left({ }^{\circ} \mathrm{E}\right)$ & 纬度 Latitude $\left({ }^{\circ} \mathrm{N}\right)$ & 数据来源 Sources & 位置 Location \\
\hline 49 & 125.15 & 53.06 & 电话访谈 & 黑龙江省/大兴安岭地区/塔河县 \\
\hline 50 & 124.84 & 52.57 & 电话访谈 & 黑龙江省/大兴安岭地区/塔河县 \\
\hline 51 & 124.40 & 51.61 & 实地访问调查 & 黑龙江省/大兴安岭地区/新林区 \\
\hline 52 & 125.31 & 51.80 & 实地访问调查 & 黑龙江省/大兴安岭地区/新林区 \\
\hline 53 & 125.30 & 51.79 & 实地访问调查 & 黑龙江省/大兴安岭地区/新林区 \\
\hline 54 & 124.12 & 51.42 & 实地访问调查 & 黑龙江省/大兴安岭地区/新林区 \\
\hline 55 & 124.22 & 51.61 & 实地访问调查 & 黑龙江省/大兴安岭地区/新林区 \\
\hline 56 & 128.01 & 44.18 & 文献记载 & 黑龙江省/哈尔滨市/五常市 \\
\hline 57 & 126.57 & 50.17 & 文献记载 & 黑龙江省/黑河市/爱辉区 \\
\hline 58 & 126.93 & 49.59 & 文献记载 & 黑龙江省/黑河市/爱辉区 \\
\hline 59 & 126.88 & 49.59 & 问卷调查 & 黑龙江省/黑河市/爱辉区 \\
\hline 60 & 127.19 & 49.86 & 问卷调查 & 黑龙江省/黑河市/爱辉区 \\
\hline 61 & 126.32 & 50.27 & 问卷调查 & 黑龙江省/黑河市/爱辉区 \\
\hline 62 & 126.92 & 50.35 & 实地访问调查 & 黑龙江省/黑河市/爱辉区 \\
\hline 63 & 127.23 & 49.87 & 实地访问调查 & 黑龙江省/黑河市/爱辉区 \\
\hline 64 & 127.21 & 48.44 & 文献记载 & 黑龙江省/黑河市/北安市 \\
\hline 65 & 126.01 & 50.78 & 文献记载 & 黑龙江省/黑河市/嫩江市 \\
\hline 66 & 127.02 & 49.55 & 文献记载 & 黑龙江省/黑河市/孙吴县 \\
\hline 67 & 127.04 & 49.54 & 文献记载 & 黑龙江省/黑河市/孙吴县 \\
\hline 68 & 127.07 & 48.57 & 文献记载 & 黑龙江省/黑河市/五大连池市 \\
\hline 69 & 126.62 & 48.90 & 实地访问调查 & 黑龙江省/黑河市/五大连池市 \\
\hline 70 & 128.14 & 49.36 & 文献记载 & 黑龙江省/黑河市/逊克县 \\
\hline 71 & 128.89 & 48.77 & 文献记载 & 黑龙江省/黑河市/逊克县 \\
\hline 72 & 128.40 & 48.48 & 实地访问调查 & 黑龙江省/黑河市/逊克县 \\
\hline 73 & 128.38 & 48.49 & 实地访问调查 & 黑龙江省/黑河市/逊克县 \\
\hline 74 & 128.63 & 48.78 & 实地访问调查 & 黑龙江省/黑河市/逊克县 \\
\hline 75 & 128.98 & 48.75 & 实地访问调查 & 黑龙江省/黑河市/逊克县 \\
\hline 76 & 127.94 & 49.46 & 文献记载 & 黑龙江省/黑河市/逊克县 \\
\hline 77 & 128.85 & 48.77 & 电话访谈 & 黑龙江省/黑河市/逊克县 \\
\hline 78 & 128.43 & 48.39 & 文献记载 & 黑龙江省/黑河市/逊克县 \\
\hline 79 & 128.66 & 48.97 & 文献记载 & 黑龙江省/黑河市/逊克县 \\
\hline 80 & 133.83 & 46.28 & 电话访谈 & 黑龙江省/鸡西市/虎林市 \\
\hline 81 & 134.55 & 48.40 & 文献记载 & 黑龙江省/佳木斯市/抚远市 \\
\hline 82 & 134.46 & 48.40 & 文献记载 & 黑龙江省/佳木斯市/抚远市 \\
\hline 83 & 134.66 & 48.38 & 文献记载 & 黑龙江省/佳木斯市/抚远市 \\
\hline 84 & 134.09 & 48.15 & 实地访问调查 & 黑龙江省/佳木斯市/抚远市 \\
\hline 85 & 134.53 & 48.02 & 实地访问调查 & 黑龙江省/佳木斯市/抚远市 \\
\hline 86 & 134.45 & 48.37 & 实地访问调查 & 黑龙江省/佳木斯市/抚远市 \\
\hline 87 & 134.61 & 47.55 & 实地访问调查 & 黑龙江省/佳木斯市/抚远市 \\
\hline 88 & 133.83 & 48.24 & 实地访问调查 & 黑龙江省/佳木斯市/同江市 \\
\hline 89 & 133.08 & 48.06 & 实地访问调查 & 黑龙江省/佳木斯市/同江市 \\
\hline 90 & 131.22 & 44.21 & 电话访谈 & 黑龙江省/牡丹江市/东宁市 \\
\hline 91 & 131.02 & 43.70 & 电话访谈 & 黑龙江省/牡丹江市/东宁市 \\
\hline 92 & 128.72 & 44.12 & 文献记载 & 黑龙江省/牡丹江市/宁安市 \\
\hline 93 & 132.21 & 45.95 & 电话访谈 & 黑龙江省/双鸭山市/宝清县 \\
\hline 94 & 128.97 & 47.10 & 实地访问调查 & 黑龙江省/伊春市/大等山县 \\
\hline 95 & 128.97 & 47.11 & 实地访问调查 & 黑龙江省/伊春市/大箐山县 \\
\hline 96 & 128.96 & 47.10 & 实地访问调查 & 黑龙江省/伊春市/大箐山县 \\
\hline 97 & 129.38 & 49.37 & 文献记载 & 黑龙江省/伊春市/嘉荫县 \\
\hline 98 & 129.64 & 49.09 & 实地访问调查 & 黑龙江省/伊春市/嘉荫县 \\
\hline
\end{tabular}


张超, 陈敏豪, 杨立, 庄鸿飞, 武曙红, 湛振杰, 王嘉栋, 亱晓峰 (2022) 东北地区水獭分布格局与保护优先区识别. 生物多 样性, 30, 21157. http://www.biodiversity-science.net/CN/10.17520/biods.2021157

\begin{tabular}{|c|c|c|c|c|}
\hline 编号 ID & 经度 Longitude $\left({ }^{\circ} \mathrm{E}\right)$ & 纬度 Latitude $\left({ }^{\circ} \mathrm{N}\right)$ & 数据来源 Sources & 位置 Location \\
\hline 99 & 129.88 & 48.89 & 实地访问调查 & 黑龙江省/伊春市/嘉荫县 \\
\hline 100 & 129.75 & 48.93 & 实地访问调查 & 黑龙江省/伊春市/嘉荫县 \\
\hline 101 & 129.87 & 48.90 & 电话访谈 & 黑龙江省/伊春市/嘉荫县 \\
\hline 102 & 129.41 & 48.59 & 实地访问调查 & 黑龙江省/伊春市/汤旺县 \\
\hline 103 & 129.42 & 48.59 & 实地访问调查 & 黑龙江省/伊春市/汤旺县 \\
\hline 104 & 129.40 & 48.60 & 实地访问调查 & 黑龙江省/伊春市/汤旺县 \\
\hline 105 & 129.39 & 48.60 & 实地访问调查 & 黑龙江省/伊春市/汤旺县 \\
\hline 106 & 129.70 & 48.50 & 实地访问调查 & 黑龙江省/伊春市/汤旺县 \\
\hline 107 & 129.29 & 48.52 & 电话访谈 & 黑龙江省/伊春市/汤旺县 \\
\hline 108 & 129.05 & 46.73 & 文献记载 & 黑龙江省/伊春市/铁力市 \\
\hline 109 & 129.16 & 46.83 & 文献记载 & 黑龙江省/伊春市/铁力市 \\
\hline 110 & 129.05 & 47.81 & 实地访问调查 & 黑龙江省/伊春市/乌翠区 \\
\hline 111 & 129.10 & 47.78 & 实地访问调查 & 黑龙江省/伊春市/乌翠区 \\
\hline 112 & 128.79 & 47.46 & 文献记载 & 黑龙江省/伊春市/乌翠区 \\
\hline 113 & 129.26 & 47.74 & 实地访问调查 & 黑龙江省/伊春市/伊美区 \\
\hline 114 & 129.45 & 47.90 & 实地访问调查 & 黑龙江省/伊春市/伊美区 \\
\hline 115 & 127.16 & 42.59 & 电话访谈 & 吉林省/白山市/抚松县 \\
\hline 116 & 126.56 & 41.76 & 文献记载 & 吉林省/白山市/浑江区 \\
\hline 117 & 126.38 & 42.30 & 文献记载 & 吉林省/通化市/辉南县 \\
\hline 118 & 126.24 & 41.31 & 电话访谈 & 吉林省/通化市/集安市 \\
\hline 119 & 126.11 & 42.10 & 文献记载 & 吉林省/通化市/柳河县 \\
\hline 120 & 128.00 & 42.35 & 实地访问调查 & 吉林省/延边州/安图县 \\
\hline 121 & 128.09 & 42.34 & 实地访问调查 & 吉林省/延边州/安图县 \\
\hline 122 & 128.04 & 42.38 & 实地访问调查 & 吉林省/延边州/安图县 \\
\hline 123 & 127.98 & 42.28 & 电话访谈 & 吉林省/延边州/安图县 \\
\hline 124 & 128.09 & 43.90 & 文献记载 & 吉林省/延边州/敦化市 \\
\hline 125 & 130.41 & 43.18 & 电话访谈 & 吉林省/延边州/珲春市 \\
\hline 126 & 130.02 & 43.59 & 电话访谈 & 吉林省/延边州/汪清县 \\
\hline 127 & 130.44 & 43.52 & 电话访谈 & 吉林省/延边州/汪清县 \\
\hline 128 & 122.57 & 48.79 & 电话访谈 & 内蒙古自治区/呼伦贝尔市/阿荣旗 \\
\hline 129 & 120.75 & 52.62 & 实地访问调查 & 内蒙古自治区/呼伦贝尔市/额尔古纳市 \\
\hline 130 & 121.05 & 52.70 & 实地访问调查 & 内蒙古自治区/呼伦贝尔市/额尔古纳市 \\
\hline 131 & 121.21 & 52.23 & 实地访问调查 & 内蒙古自治区/呼伦贝尔市/额尔古纳市 \\
\hline 132 & 120.60 & 52.58 & 实地访问调查 & 内蒙古自治区/呼伦贝尔市/额尔古纳市 \\
\hline 133 & 120.93 & 51.89 & 实地访问调查 & 内蒙古自治区/呼伦贝尔市/额尔古纳市 \\
\hline 134 & 121.46 & 53.20 & 实地访问调查 & 内蒙古自治区/呼伦贝尔市/额尔古纳市 \\
\hline 135 & 121.40 & 53.01 & 实地访问调查 & 内蒙古自治区/呼伦贝尔市/额尔古纳市 \\
\hline 136 & 121.25 & 52.45 & 实地访问调查 & 内蒙古自治区/呼伦贝尔市/额尔古纳市 \\
\hline 137 & 121.18 & 52.18 & 实地访问调查 & 内蒙古自治区/呼伦贝尔市/额尔古纳市 \\
\hline 138 & 120.82 & 51.99 & 电话访谈 & 内蒙古自治区/呼伦贝尔市/额尔古纳市 \\
\hline 139 & 121.00 & 51.81 & 电话访谈 & 内蒙古自治区/呼伦贝尔市/额尔古纳市 \\
\hline 140 & 120.77 & 51.35 & 实地访问调查 & 内蒙古自治区/呼伦贝尔市/额尔古纳市 \\
\hline 141 & 120.59 & 51.38 & 实地访问调查 & 内蒙古自治区/呼伦贝尔市/额尔古纳市 \\
\hline 142 & 120.71 & 50.41 & 电话访谈 & 内蒙古自治区/呼伦贝尔市/额尔古纳市 \\
\hline 143 & 121.10 & 52.80 & 电话访谈 & 内蒙古自治区/呼伦贝尔市/额尔古纳市 \\
\hline 144 & 120.43 & 51.80 & 电话访谈 & 内蒙古自治区/呼伦贝尔市/额尔古纳市 \\
\hline 145 & 121.70 & 52.10 & 电话访谈 & 内蒙古自治区/呼伦贝尔市/额尔古纳市 \\
\hline 146 & 121.22 & 52.24 & 电话访谈 & 内蒙古自治区/呼伦贝尔市/额尔古纳市 \\
\hline 147 & 121.43 & 52.91 & 电话访谈 & 内蒙古自治区/呼伦贝尔市/额尔古纳市 \\
\hline 148 & 120.79 & 52.84 & 电话访谈 & 内蒙古自治区/呼伦贝尔市/额尔古纳市 \\
\hline
\end{tabular}


张超, 陈敏豪, 杨立, 庄鸿飞, 武曙红, 湛振杰, 王嘉栋, 亱晓峰 (2022) 东北地区水獭分布格局与保护优先区识别. 生物多 样性, 30, 21157. http://www.biodiversity-science.net/CN/10.17520/biods.2021157

\begin{tabular}{|c|c|c|c|c|}
\hline 编号 ID & 经度 Longitude $\left({ }^{\circ} \mathrm{E}\right)$ & 纬度 Latitude $\left({ }^{\circ} \mathrm{N}\right)$ & 数据来源 Sources & 位置 Location \\
\hline 149 & 120.24 & 52.78 & 电话访谈 & 内蒙古自治区/呼伦贝尔市/额尔古纳市 \\
\hline 150 & 121.41 & 52.00 & 电话访谈 & 内蒙古自治区/呼伦贝尔市/额尔古纳市 \\
\hline 151 & 121.51 & 53.12 & 电话访谈 & 内蒙古自治区/呼伦贝尔市/额尔古纳市 \\
\hline 152 & 121.20 & 52.36 & 电话访谈 & 内蒙古自治区/呼伦贝尔市/额尔古纳市 \\
\hline 153 & 121.21 & 52.19 & 电话访谈 & 内蒙古自治区/呼伦贝尔市/额尔古纳市 \\
\hline 154 & 122.73 & 49.94 & 实地访问调查 & 内蒙古自治区/呼伦贝尔市/鄂伦春自治旗 \\
\hline 155 & 122.73 & 49.98 & 实地访问调查 & 内蒙古自治区/呼伦贝尔市/鄂伦春自治旗 \\
\hline 156 & 122.51 & 50.39 & 实地访问调查 & 内蒙古自治区/呼伦贝尔市/鄂伦春自治旗 \\
\hline 157 & 122.63 & 50.28 & 实地访问调查 & 内蒙古自治区/呼伦贝尔市/鄂伦春自治旗 \\
\hline 158 & 122.59 & 50.65 & 实地访问调查 & 内蒙古自治区/呼伦贝尔市/鄂伦春自治旗 \\
\hline 159 & 122.69 & 50.66 & 实地访问调查 & 内蒙古自治区/呼伦贝尔市/鄂伦春自治旗 \\
\hline 160 & 122.82 & 50.64 & 实地访问调查 & 内蒙古自治区/呼伦贝尔市/鄂伦春自治旗 \\
\hline 161 & 123.15 & 49.47 & 实地访问调查 & 内蒙古自治区/呼伦贝尔市/鄂伦春自治旗 \\
\hline 162 & 122.90 & 51.11 & 实地访问调查 & 内蒙古自治区/呼伦贝尔市/鄂伦春自治旗 \\
\hline 163 & 122.96 & 50.96 & 实地访问调查 & 内蒙古自治区/呼伦贝尔市/鄂伦春自治旗 \\
\hline 164 & 122.99 & 51.13 & 实地访问调查 & 内蒙古自治区/呼伦贝尔市/鄂伦春自治旗 \\
\hline 165 & 122.96 & 50.88 & 实地访问调查 & 内蒙古自治区/呼伦贝尔市/鄂伦春自治旗 \\
\hline 166 & 122.96 & 50.84 & 实地访问调查 & 内蒙古自治区/呼伦贝尔市/鄂伦春自治旗 \\
\hline 167 & 123.09 & 50.72 & 实地访问调查 & 内蒙古自治区/呼伦贝尔市/鄂伦春自治旗 \\
\hline 168 & 123.12 & 50.65 & 实地访问调查 & 内蒙古自治区/呼伦贝尔市/鄂伦春自治旗 \\
\hline 169 & 122.84 & 51.27 & 实地访问调查 & 内蒙古自治区/呼伦贝尔市/鄂伦春自治旗 \\
\hline 170 & 123.02 & 50.79 & 实地访问调查 & 内蒙古自治区/呼伦贝尔市/鄂伦春自治旗 \\
\hline 171 & 122.51 & 50.13 & 实地访问调查 & 内蒙古自治区/呼伦贝尔市/鄂伦春自治旗 \\
\hline 172 & 125.14 & 51.29 & 实地访问调查 & 内蒙古自治区/呼伦贝尔市/鄂伦春自治旗 \\
\hline 173 & 125.30 & 51.38 & 实地访问调查 & 内蒙古自治区/呼伦贝尔市/鄂伦春自治旗 \\
\hline 174 & 122.88 & 51.17 & 实地访问调查 & 内蒙古自治区/呼伦贝尔市/鄂伦春自治旗 \\
\hline 175 & 125.41 & 51.19 & 实地访问调查 & 内蒙古自治区/呼伦贝尔市/鄂伦春自治旗 \\
\hline 176 & 122.89 & 51.20 & 实地访问调查 & 内蒙古自治区/呼伦贝尔市/鄂伦春自治旗 \\
\hline 177 & 122.89 & 51.20 & 实地访问调查 & 内蒙古自治区/呼伦贝尔市/鄂伦春自治旗 \\
\hline 178 & 122.98 & 50.93 & 粪便采集 & 内蒙古自治区/呼伦贝尔市/鄂伦春自治旗 \\
\hline 179 & 123.08 & 50.73 & 实地访问调查 & 内蒙古自治区/呼伦贝尔市/鄂伦春自治旗 \\
\hline 180 & 123.62 & 50.17 & 实地访问调查 & 内蒙古自治区/呼伦贝尔市/鄂伦春自治旗 \\
\hline 181 & 123.05 & 50.73 & 实地访问调查 & 内蒙古自治区/呼伦贝尔市/鄂伦春自治旗 \\
\hline 182 & 125.28 & 51.13 & 实地访问调查 & 内蒙古自治区/呼伦贝尔市/鄂伦春自治旗 \\
\hline 183 & 122.74 & 51.51 & 实地访问调查 & 内蒙古自治区/呼伦贝尔市/鄂伦春自治旗 \\
\hline 184 & 122.62 & 50.24 & 粪便采集 & 内蒙古自治区/呼伦贝尔市/鄂伦春自治旗 \\
\hline 185 & 124.34 & 50.62 & 实地访问调查 & 内蒙古自治区/呼伦贝尔市/鄂伦春自治旗 \\
\hline 186 & 124.30 & 50.86 & 实地访问调查 & 内蒙古自治区/呼伦贝尔市/鄂伦春自治旗 \\
\hline 187 & 124.00 & 50.85 & 实地访问调查 & 内蒙古自治区/呼伦贝尔市/鄂伦春自治旗 \\
\hline 188 & 125.43 & 51.19 & 电话访谈 & 内蒙古自治区/呼伦贝尔市/鄂伦春自治旗 \\
\hline 189 & 125.39 & 51.44 & 电话访谈 & 内蒙古自治区/呼伦贝尔市/鄂伦春自治旗 \\
\hline 190 & 125.14 & 51.57 & 电话访谈 & 内蒙古自治区/呼伦贝尔市/鄂伦春自治旗 \\
\hline 191 & 125.29 & 51.13 & 电话访谈 & 内蒙古自治区/呼伦贝尔市/鄂伦春自治旗 \\
\hline 192 & 123.42 & 49.51 & 电话访谈 & 内蒙古自治区/呼伦贝尔市/鄂伦春自治旗 \\
\hline 193 & 123.62 & 50.75 & 电话访谈 & 内蒙古自治区/呼伦贝尔市/鄂伦春自治旗 \\
\hline 194 & 123.04 & 50.76 & 电话访谈 & 内蒙古自治区/呼伦贝尔市/鄂伦春自治旗 \\
\hline 195 & 125.35 & 51.29 & 电话访谈 & 内蒙古自治区/呼伦贝尔市/鄂伦春自治旗 \\
\hline 196 & 124.38 & 50.64 & 电话访谈 & 内蒙古自治区/呼伦贝尔市/鄂伦春自治旗 \\
\hline 197 & 122.26 & 49.18 & 电话访谈 & 内蒙古自治区/呼伦贝尔市/鄂伦春自治旗 \\
\hline 198 & 120.62 & 48.64 & 实地访问调查 & 内蒙古自治区/呼伦贝尔市/鄂温克族自治旗 \\
\hline
\end{tabular}


张超, 陈敏豪, 杨立, 庄鸿飞, 武曙红, 湛振杰, 王嘉栋, 亱晓峰 (2022) 东北地区水獭分布格局与保护优先区识别. 生物多 样性, 30, 21157. http://www.biodiversity-science.net/CN/10.17520/biods.2021157

\begin{tabular}{|c|c|c|c|c|}
\hline 编号 ID & 经度 Longitude $\left({ }^{\circ} \mathrm{E}\right)$ & 纬度 Latitude $\left({ }^{\circ} \mathrm{N}\right)$ & 数据来源 Sources & 位置 Location \\
\hline 199 & 120.69 & 48.62 & 实地访问调查 & 内蒙古自治区/呼伦贝尔市/鄂温克族自治旗 \\
\hline 200 & 120.63 & 48.41 & 实地访问调查 & 内蒙古自治区/呼伦贝尔市/鄂温克族自治旗 \\
\hline 201 & 120.59 & 48.45 & 实地访问调查 & 内蒙古自治区/呼伦贝尔市/鄂温克族自治旗 \\
\hline 202 & 120.76 & 48.33 & 实地访问调查 & 内蒙古自治区/呼伦贝尔市/鄂温克族自治旗 \\
\hline 203 & 120.63 & 48.45 & 电话访谈 & 内蒙古自治区/呼伦贝尔市/鄂温克族自治旗 \\
\hline 204 & 122.05 & 52.17 & 实地访问调查 & 内蒙古自治区/呼伦贝尔市/根河市 \\
\hline 205 & 121.46 & 51.20 & 实地访问调查 & 内蒙古自治区/呼伦贝尔市/根河市 \\
\hline 206 & 122.65 & 51.47 & 文献记载 & 内蒙古自治区/呼伦贝尔市/根河市 \\
\hline 207 & 121.77 & 51.56 & 实地访问调查 & 内蒙古自治区/呼伦贝尔市/根河市 \\
\hline 208 & 121.71 & 51.55 & 实地访问调查 & 内蒙古自治区/呼伦贝尔市/根河市 \\
\hline 209 & 121.48 & 51.36 & 实地访问调查 & 内蒙古自治区/呼伦贝尔市/根河市 \\
\hline 210 & 121.38 & 51.29 & 实地访问调查 & 内蒙古自治区/呼伦贝尔市/根河市 \\
\hline 211 & 121.30 & 51.37 & 实地访问调查 & 内蒙古自治区/呼伦贝尔市/根河市 \\
\hline 212 & 121.67 & 50.86 & 实地访问调查 & 内蒙古自治区/呼伦贝尔市/根河市 \\
\hline 213 & 121.61 & 50.83 & 实地访问调查 & 内蒙古自治区/呼伦贝尔市/根河市 \\
\hline 214 & 122.62 & 51.46 & 实地访问调查 & 内蒙古自治区/呼伦贝尔市/根河市 \\
\hline 215 & 121.86 & 51.56 & 实地访问调查 & 内蒙古自治区/呼伦贝尔市/根河市 \\
\hline 216 & 120.55 & 50.72 & 实地访问调查 & 内蒙古自治区/呼伦贝尔市/根河市 \\
\hline 217 & 120.65 & 50.76 & 实地访问调查 & 内蒙古自治区/呼伦贝尔市/根河市 \\
\hline 218 & 121.32 & 50.68 & 粪便采集 & 内蒙古自治区/呼伦贝尔市/根河市 \\
\hline 219 & 121.32 & 50.67 & 粪便采集 & 内蒙古自治区/呼伦贝尔市/根河市 \\
\hline 220 & 121.64 & 50.85 & 实地访问调查 & 内蒙古自治区/呼伦贝尔市/根河市 \\
\hline 221 & 122.61 & 51.72 & 电话访谈 & 内蒙古自治区/呼伦贝尔市/根河市 \\
\hline 222 & 122.67 & 51.76 & 电话访谈 & 内蒙古自治区/呼伦贝尔市/根河市 \\
\hline 223 & 122.65 & 51.69 & 电话访谈 & 内蒙古自治区/呼伦贝尔市/根河市 \\
\hline 224 & 122.58 & 51.63 & 电话访谈 & 内蒙古自治区/呼伦贝尔市/根河市 \\
\hline 225 & 122.67 & 51.65 & 电话访谈 & 内蒙古自治区/呼伦贝尔市/根河市 \\
\hline 226 & 122.64 & 51.58 & 电话访谈 & 内蒙古自治区/呼伦贝尔市/根河市 \\
\hline 227 & 122.61 & 51.54 & 电话访谈 & 内蒙古自治区/呼伦贝尔市/根河市 \\
\hline 228 & 122.51 & 51.62 & 电话访谈 & 内蒙古自治区/呼伦贝尔市/根河市 \\
\hline 229 & 122.70 & 51.71 & 电话访谈 & 内蒙古自治区/呼伦贝尔市/根河市 \\
\hline 230 & 122.57 & 51.44 & 电话访谈 & 内蒙古自治区/呼伦贝尔市/根河市 \\
\hline 231 & 122.61 & 51.65 & 电话访谈 & 内蒙古自治区/呼伦贝尔市/根河市 \\
\hline 232 & 122.41 & 52.01 & 电话访谈 & 内蒙古自治区/呼伦贝尔市/根河市 \\
\hline 233 & 121.91 & 51.85 & 电话访谈 & 内蒙古自治区/呼伦贝尔市/根河市 \\
\hline 234 & 122.41 & 52.26 & 电话访谈 & 内蒙古自治区/呼伦贝尔市/根河市 \\
\hline 235 & 122.01 & 51.58 & 电话访谈 & 内蒙古自治区/呼伦贝尔市/根河市 \\
\hline 236 & 121.25 & 48.11 & 实地访问调查 & 内蒙古自治区/呼伦贝尔市/牙克石市 \\
\hline 237 & 120.90 & 49.20 & 实地访问调查 & 内蒙古自治区/呼伦贝尔市/牙克石市 \\
\hline 238 & 121.22 & 47.93 & 实地访问调查 & 内蒙古自治区/呼伦贝尔市/牙克石市 \\
\hline 239 & 120.81 & 49.24 & 实地访问调查 & 内蒙古自治区/呼伦贝尔市/牙克石市 \\
\hline 240 & 121.72 & 48.66 & 文献记载 & 内蒙古自治区/呼伦贝尔市/牙克石市 \\
\hline 241 & 121.24 & 47.69 & 实地访问调查 & 内蒙古自治区/呼伦贝尔市/扎兰屯市 \\
\hline 242 & 120.66 & 47.48 & 实地访问调查 & 内蒙古自治区/呼伦贝尔市/扎兰屯市 \\
\hline 243 & 121.16 & 47.80 & 实地访问调查 & 内蒙古自治区/呼伦贝尔市/扎兰屯市 \\
\hline 244 & 121.70 & 48.08 & 文献记载 & 内蒙古自治区/呼伦贝尔市/扎兰屯市 \\
\hline 245 & 120.24 & 47.47 & 实地访问调查 & 内蒙古自治区/兴安盟/阿尔山市 \\
\hline 246 & 120.32 & 47.29 & 实地访问调查 & 内蒙古自治区/兴安盟/阿尔山市 \\
\hline 247 & 120.48 & 47.27 & 实地访问调查 & 内蒙古自治区/兴安盟/阿尔山市 \\
\hline
\end{tabular}


张超, 陈敏豪, 杨立, 庄鸿飞, 武曙红, 湛振杰, 王嘉栋, 奕晓峰 (2022) 东北地区水獭分布格局与保护优先区识别. 生物多 样性, 30, 21157. http://www.biodiversity-science.net/CN/10.17520/biods.2021157
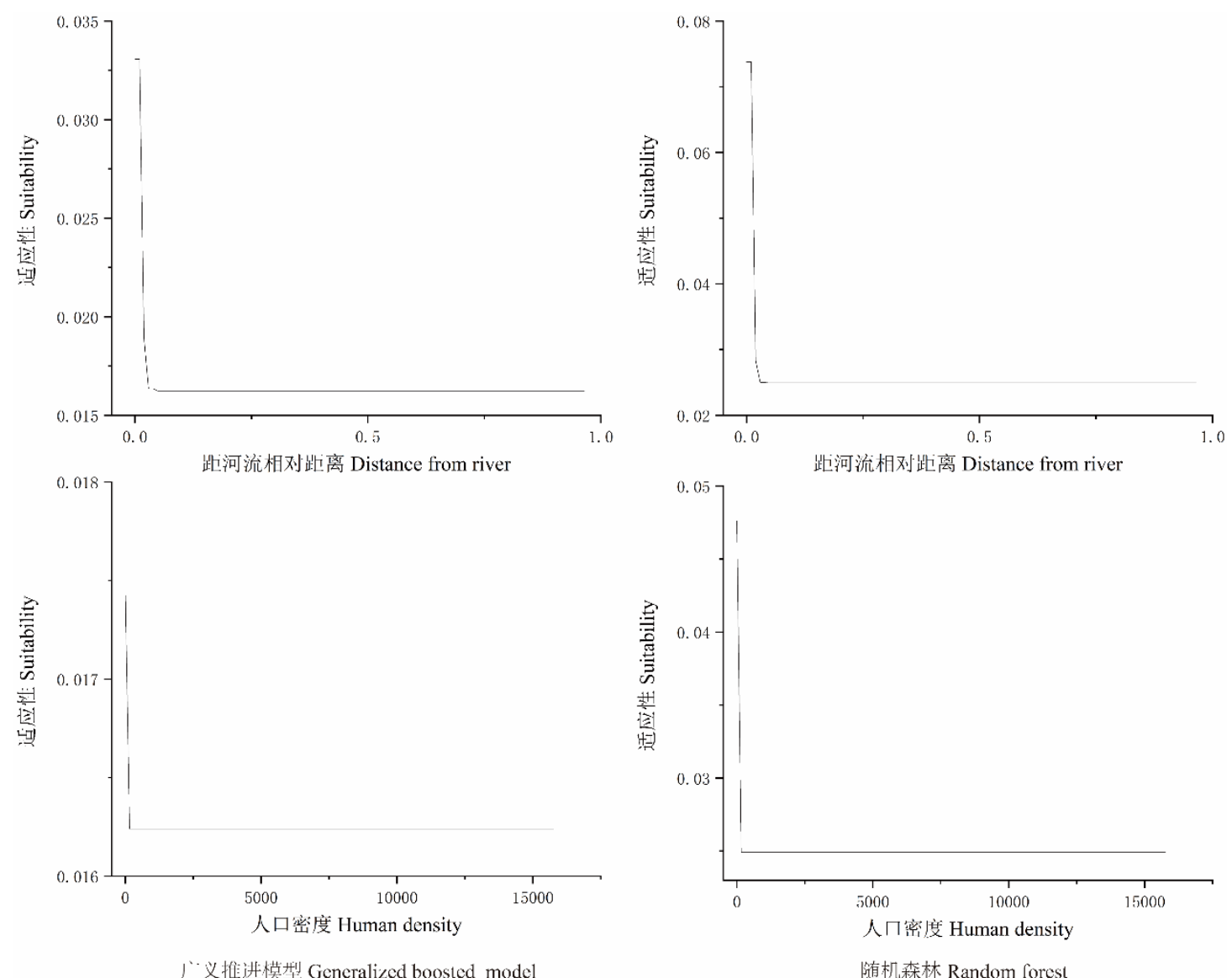

附录 2 水獭适应性对重要变量的响应曲线

Appendix 2 Response curves of suitability of otter to important variables 
张超, 陈敏豪, 杨立, 庄鸿飞, 武曙红, 湛振杰, 王嘉栋, 奕晓峰 (2022) 东北地区水獭分布格局与保护优先区识别. 生物多 样性, 30, 21157. http://www.biodiversity-science.net/CN/10.17520/biods.2021157

附录 3 水獭潜在分布区内的国家级自然保护区

Appendix 3 National nature reserves in potential distribution of the otter

\begin{tabular}{|c|c|c|}
\hline 编号 ID & 省/自治区 Province/Autonomous region & 自然保护区名称 Name of nature reserves \\
\hline 1 & 内蒙古 & 内蒙古毕拉河国家级自然保护区 \\
\hline 2 & 内蒙古 & 内蒙古红花尔基樟子松国家级自然保护区 \\
\hline 3 & 内蒙古 & 内蒙古汗马国家级自然保护区 \\
\hline 4 & 内蒙古 & 内蒙古额尔古纳国家级自然保护区 \\
\hline 5 & 黑龙江 & 黑龙江大沾河湿地国家级自然保护区 \\
\hline 6 & 黑龙江 & 黑龙江中央站黑嘴松鸡国家级自然保护区 \\
\hline 7 & 黑龙江 & 黑龙江公别拉河国家级自然保护区 \\
\hline 8 & 黑龙江 & 黑龙江胜山国家级自然保护区 \\
\hline 9 & 黑龙江 & 黑龙江省乌伊岭国家级自然保护区 \\
\hline 10 & 黑龙江 & 黑龙江翠北湿地国家级自然保护区 \\
\hline 11 & 黑龙江 & 黑龙江丰林国家级自然保护区 \\
\hline 12 & 黑龙江 & 黑龙江红星湿地国家级自然保护区 \\
\hline 13 & 黑龙江 & 黑龙江新青白头鹤国家级自然保护区 \\
\hline 14 & 黑龙江 & 乌马河紫貂国家级自然保护区 \\
\hline 15 & 黑龙江 & 黑龙江碧水中华秋沙鸭国家级自然保护区 \\
\hline 16 & 黑龙江 & 黑龙江朗乡国家级自然保护区 \\
\hline 17 & 黑龙江 & 黑龙江凉水国家级自然保护区 \\
\hline 18 & 黑龙江 & 黑龙江茅兰沟国家级自然保护区 \\
\hline 19 & 黑龙江 & 黑龙江友好国家级自然保护区 \\
\hline 20 & 黑龙江 & 黑龙江平顶山国家级自然保护区 \\
\hline 21 & 黑龙江 & 黑龙江大峡谷国家级自然保护区 \\
\hline 22 & 黑龙江 & 黑龙江细鳞河国家级自然保护区 \\
\hline 23 & 黑龙江 & 黑龙江太平沟国家级自然保护区 \\
\hline 24 & 黑龙江 & 黑龙江东方红国家级自然保护区 \\
\hline 25 & 黑龙江 & 黑龙江凤凰山国家级自然保护区 \\
\hline 26 & 黑龙江 & 黑龙江兴凯湖国家级自然保护区 \\
\hline 27 & 黑龙江 & 黑龙江珍宝岛湿地国家级自然保护区 \\
\hline 28 & 黑龙江 & 黑龙江八岔岛国家级自然保护区 \\
\hline 29 & 黑龙江 & 黑龙江洪河国家级自然保护区 \\
\hline 30 & 黑龙江 & 黑龙江三江国家级自然保护区 \\
\hline 31 & 黑龙江 & 黑龙江省挠力河国家级自然保护区 \\
\hline 32 & 黑龙江 & 黑龙江老爷岭东北虎国家级自然保护区 \\
\hline 33 & 黑龙江 & 黑龙江穆棱东北红豆杉国家级自然保护区 \\
\hline 34 & 黑龙江 & 黑龙江小北湖国家级自然保护区 \\
\hline 35 & 黑龙江 & 黑龙江饶河东北黑蜂国家级自然保护区 \\
\hline 36 & 黑龙江 & 黑龙江北极村国家级自然保护区 \\
\hline 37 & 黑龙江 & 黑龙江岭峰国家级自然保护区 \\
\hline 38 & 黑龙江 & 黑龙江多布库尔国家级自然保护区 \\
\hline 39 & 黑龙江 & 黑龙江南瓮河国家级自然保护区 \\
\hline 40 & 黑龙江 & 黑龙江呼中国家级自然保护区 \\
\hline 41 & 黑龙江 & 黑龙江绰纳河国家级自然保护区 \\
\hline 42 & 黑龙江 & 黑龙江盘中国家级自然保护区 \\
\hline 43 & 黑龙江 & 黑龙江双河国家级自然保护区 \\
\hline 44 & 黑龙江 & 黑龙江黑瞎子岛国家级自然保护区 \\
\hline
\end{tabular}


张超, 陈敏豪, 杨立, 庄鸿飞, 武曙红, 湛振杰, 王嘉栋, 奕晓峰 (2022) 东北地区水獭分布格局与保护优先区识别. 生物多 样性, 30, 21157. http://www.biodiversity-science.net/CN/10.17520/biods.2021157

\begin{tabular}{lll}
\hline 编号 ID & 省/自治区 Province/Autonomous region & 自然保护区名称 Name of nature reserves \\
\hline 45 & 吉林 & 吉林白山原看国家级自然保护区 \\
46 & 吉林 & 吉林哈泥国家级自然保护区 \\
47 & 吉林 & 吉林黄泥河国家级自然保护区 \\
48 & 吉林 & 吉林珲春东北虎国家级自然保护区 \\
49 & 吉林 & 吉林集安国家级自然保护区 \\
50 & 吉林 & 吉林靖宇国家级自然保护区 \\
51 & 吉林 & 吉林龙湾国家级自然保护区 \\
52 & 吉林 & 吉林松花江三湖国家级自然保护区 \\
53 & 吉林 & 吉林天佛指山国家级自然保护区 \\
54 & 吉林 & 吉林通化石湖国家级自然保护区 \\
55 & 吉林 & 吉林头道松花江上游国家级自然保护区 \\
56 & 吉林 & 吉林汪清国家级自然保护区 \\
57 & 吉林 & 吉林鸭绿江上游国家级自然保护区 \\
58 & 吉林 & 吉林雁鸣湖国家级自然保护区 \\
59 & 吉林 & 吉林园池湿地国家级自然保护区 \\
60 & 吉林 & 吉林甑峰岭国家级自然保护区 \\
61 & 吉林 & 吉林长白山国家级自然保护区 \\
62 & 辽宁 & 辽宁白石砬子国家级自然保护区 \\
63 & 辽宁 & 辽宁老秃顶子国家级自然保护区 \\
\hline & &
\end{tabular}


张超, 陈敏豪, 杨立, 庄鸿飞, 武曙红, 湛振杰, 王嘉栋, 奕晓峰 (2022) 东北地区水獭分布格局与保护优先区识别. 生物多 样性, 30, 21157. http://www.biodiversity-science.net/CN/10.17520/biods.2021157

附录 4 水獭保护优先区内的国家级自然保护区

Appendix 4 National nature reserves in conservation priority areas of the otter

\begin{tabular}{|c|c|c|}
\hline 编号 ID & 省/自治区 Province/Autonomous region & 自然保护区名称 Name of nature reserves \\
\hline 1 & 内蒙古 & 内蒙古毕拉河国家级自然保护区 \\
\hline 2 & 内蒙古 & 内蒙古红花尔基樟子松国家级自然保护区 \\
\hline 3 & 内蒙古 & 内蒙古汗马国家级自然保护区 \\
\hline 4 & 内蒙古 & 内蒙古额尔古纳国家级自然保护区 \\
\hline 5 & 黑龙江 & 黑龙江大沾河湿地国家级自然保护区 \\
\hline 6 & 黑龙江 & 黑龙江省乌伊岭国家级自然保护区 \\
\hline 7 & 黑龙江 & 黑龙江翠北湿地国家级自然保护区 \\
\hline 8 & 黑龙江 & 黑龙江红星湿地国家级自然保护区 \\
\hline 9 & 黑龙江 & 黑龙江茅兰沟国家级自然保护区 \\
\hline 10 & 黑龙江 & 黑龙江友好国家级自然保护区 \\
\hline 11 & 黑龙江 & 岭峰国家级自然保护区 \\
\hline 12 & 黑龙江 & 多布库尔国家级自然保护区 \\
\hline 13 & 黑龙江 & 南瓮河国家级自然保护区 \\
\hline 14 & 黑龙江 & 呼中国家级自然保护区 \\
\hline 15 & 黑龙江 & 绰纳河国家级自然保护区 \\
\hline 16 & 黑龙江 & 黑龙江黑瞎子岛自然保护区 \\
\hline 17 & 吉林 & 吉林白山原看国家级自然保护区 \\
\hline 18 & 吉林 & 吉林哈泥国家级自然保护区 \\
\hline 19 & 吉林 & 吉林黄泥河国家级自然保护区 \\
\hline 20 & 吉林 & 吉林珲春东北虎国家级自然保护区 \\
\hline 21 & 吉林 & 吉林集安国家级自然保护区 \\
\hline 22 & 吉林 & 吉林靖宇国家级自然保护区 \\
\hline 23 & 吉林 & 吉林松花江三湖国家级自然保护区 \\
\hline 24 & 吉林 & 吉林通化石湖国家级自然保护区 \\
\hline 25 & 吉林 & 吉林头道松花江上游国家级自然保护区 \\
\hline 26 & 吉林 & 吉林汪清国家级自然保护区 \\
\hline 27 & 吉林 & 吉林鸭绿江上游国家级自然保护区 \\
\hline 28 & 吉林 & 吉林园池湿地国家级自然保护区 \\
\hline 29 & 吉林 & 吉林甑峰岭国家级自然保护区 \\
\hline 30 & 吉林 & 吉林长白山国家级自然保护区 \\
\hline 31 & 辽宁 & 辽宁白石砬子国家级自然保护区 \\
\hline 32 & 辽宁 & 辽宁老秃顶子国家级自然保护区 \\
\hline
\end{tabular}

